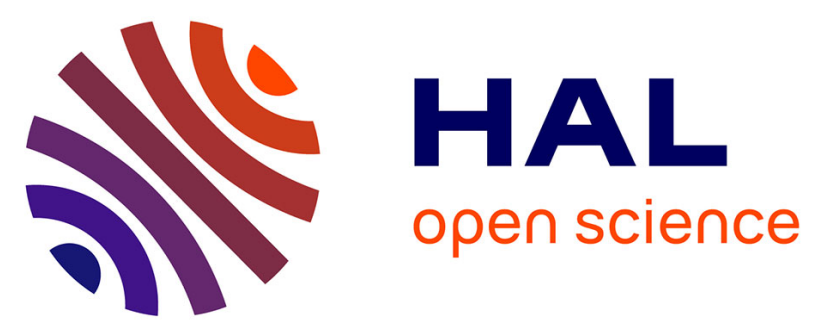

\title{
Homo- and heterotypic cell-cell contacts in Merkel cells and Merkel cell carcinomas: surprising heterogeneity and indications for cadherin switching
}

Anna Maria Werling, Yvette Doerflinger, Johanna M. Brandner, Franca Fuchs, Jürgen C. Becker, David Schrama, Hjalmar Kurzen, Sergij Goerdt, Wiebke Katharina Peitsch

\section{To cite this version:}

Anna Maria Werling, Yvette Doerflinger, Johanna M. Brandner, Franca Fuchs, Jürgen C. Becker, et al.. Homo- and heterotypic cell-cell contacts in Merkel cells and Merkel cell carcinomas: surprising heterogeneity and indications for cadherin switching. Histopathology, 2011, 58 (2), pp.286. 10.1111/j.1365-2559.2011.03748.x . hal-00614749

\author{
HAL Id: hal-00614749 \\ https://hal.science/hal-00614749
}

Submitted on 16 Aug 2011

HAL is a multi-disciplinary open access archive for the deposit and dissemination of scientific research documents, whether they are published or not. The documents may come from teaching and research institutions in France or abroad, or from public or private research centers.
L'archive ouverte pluridisciplinaire HAL, est destinée au dépôt et à la diffusion de documents scientifiques de niveau recherche, publiés ou non, émanant des établissements d'enseignement et de recherche français ou étrangers, des laboratoires publics ou privés. 


\section{Histopathology}

\section{Homo- and heterotypic cell-cell contacts in Merkel cells and Merkel cell carcinomas: surprising heterogeneity and indications for cadherin switching}

\begin{tabular}{|c|c|}
\hline Journal: & Histopathology \\
\hline Manuscript ID: & HISTOP-10-09-0579.R1 \\
\hline Manuscript Type: & Original Article \\
\hline $\begin{array}{r}\text { Date Submitted by the } \\
\text { Author: }\end{array}$ & 04-Mar-2010 \\
\hline Complete List of Authors: & $\begin{array}{l}\text { Werling, Anna; University Medical Centre Mannheim, University of } \\
\text { Heidelberg, Department of Dermatology; German Cancer Research } \\
\text { Center, Helmholtz Group for Cell Biology } \\
\text { Doerflinger, Yvette; University Medical Centre Mannheim, University } \\
\text { of Heidelberg, Department of Dermatology; German Cancer } \\
\text { Research Center, Helmholtz Group for Cell Biology } \\
\text { Brandner, Johanna; University Hospital Hamburg-Eppendorf, } \\
\text { Department of Dermatology } \\
\text { Fuchs, Franca; University Hospital Hamburg-Eppendorf, } \\
\text { Department of Dermatology } \\
\text { Becker, Jürgen; University of Würzburg, Department of } \\
\text { Dermatology } \\
\text { Schrama, David; University of Würzburg, Department of } \\
\text { Dermatology } \\
\text { Kurzen, Hjalmar; Dermatological Practice; University Medical Centre } \\
\text { Mannheim, University of Heidelberg, Department of Dermatology } \\
\text { Goerdt, Sergij; University Medical Centre Mannheim, University of } \\
\text { Heidelberg, Department of Dermatology } \\
\text { Peitsch, Wiebke; University Medical Centre Mannheim, Department } \\
\text { of Dermatology }\end{array}$ \\
\hline Keywords: & $\begin{array}{l}\text { Merkel cell carcinoma, cadherin, desmosome, tight junction, Merkel } \\
\text { cell virus }\end{array}$ \\
\hline
\end{tabular}

\section{S) ScholaroNE \\ Manuscript Central}




\section{Homo- and heterotypic cell-cell contacts in Merkel cells and Merkel cell carcinomas: surprising heterogeneity and indications for cadherin switching}

Anna M. Werling ${ }^{1,2}$, Yvette Doerflinger ${ }^{1,2}$, Johanna M. Brandner ${ }^{3}$, Franca Fuchs ${ }^{3}$, Jürgen C. Becker ${ }^{4}$, David Schrama ${ }^{4}$, Hjalmar Kurzen ${ }^{1,5}$, Sergij Goerdt ${ }^{1}$, Wiebke K. Peitsch ${ }^{1,2}$

${ }^{1}$ Department of Dermatology, University Medical Centre Mannheim, University of Heidelberg, Mannheim; ${ }^{2}$ Helmholtz Group for Cell Biology, German Cancer Research Center, Heidelberg; ${ }^{3}$ Department of Dermatology, University Hospital Hamburg-Eppendorf, Hamburg; ${ }^{4}$ Department of Dermatology, University of Würzburg, Würzburg; ${ }^{5}$ Dermatological Practice, Freising, Germany

\section{Corresponding author:}

Dr. Wiebke K. Ludwig-Peitsch

Department of Dermatology, University Medical Centre Mannheim

University of Heidelberg

Theodor-Kutzer-Ufer 1-3, 68135 Mannheim, Germany

Phone: +49-621-383 1054, Fax: +49-621-383 3815

Email:w.peitsch@dkfz-heidelberg.de

Key words: Merkel cell carcinoma, cadherin, desmosome, tight junction, Merkel cell virus

Short title: Cell contacts in Merkel cells and MCCs 


\section{Abstract}

Aims: Merkel cell carcinomas (MCCs) are rare but aggressive tumours recently associated with Merkel cell polyomavirus (MCV). As development and progression of several types of carcinomas can be promoted by changes in cell adhesion proteins, we have examined homo- and heterotypic cell contacts of Merkel cells and MCCs.

Methods and Results: Merkel cells of healthy glabrous epidermis and 52 MCCs were analyzed by double-label immunostaining, immunofluorescence and confocal microscopy. Merkel cells were connected to keratinocytes by E- and P-cadherin, desmoglein 2 and desmocollin 2 . In contrast, the vast majority of MCCs $(90 \%)$ contained N-cadherin but only 67 and 65\% contained E- and P-cadherin, respectively. Interestingly, P-cadherin was absent significantly more frequently in lymph node metastases than in primary tumours and by trend in more advanced clinical stages. Moreover, major subsets of MCCs synthesized desmoglein 2 and, surprisingly, tight junction proteins. No significant differences were observed upon stratification for MCV DNA, detected in $84 \%$ of tumours by real-time PCR.

Conclusions: Assuming that MCCs originate from Merkel cells, our data indicate a switch from E- and P-cadherin to N-cadherin during tumourigenesis. Whether the unexpected heterogeneity of junctional proteins can be exploited for prognostic and therapeutic purposes will have to be examined. 


\section{Introduction}

Merkel cell carcinomas (MCCs) are uncommon but highly aggressive neuroendocrine carcinomas of the skin, mainly affecting elderly and immunosuppressed patients. They characteristically present as red or livid tumours with a smooth surface, often occurring on sun-damaged skin and developing rapidly over a few weeks or months. In up to $80 \%$ of the patients lymph nodes are affected during the course of the disease. ${ }^{1}$ Due to relatively uncharacteristic clinical features, diagnosis is based on histology and immunohistochemistry. From the histological growth pattern a trabecular, an intermediate and a small cell type can be distinguished, the first associated with the most favourable and the last with the worst prognosis. In immunohistological investigations, the simple epithelial-type cytokeratin (CK) 20 has been established as a highly specific marker. ${ }^{2}$ Moreover, a large proportion of MCCs contain neuroendocrine markers such as chromogranin $\mathrm{A}^{3}$

Despite substantial research effort, the molecular pathogenesis of MCC is still not fully understood. Expression of the anti-apoptotic protein bcl-2, down-regulation of tumour suppressor proteins such as PTEN and alterations of the p53 pathway seem to play essential roles. ${ }^{4}$ Moreover, most interestingly, a novel human polyomavirus, designated Merkel cell virus (MCV), has recently been associated with MCC. ${ }^{5}$

It is widely assumed that MCCs arise from Merkel cells, first described in 1875 as "touch cells", which possess mechanoreceptive and possibly also endocrine and neuroimmunological functions. ${ }^{6,7}$ The developmental origin of Merkel cells has been a matter of long and intense controversy; however recent evidence indicates that they are derived from the epidermis. ${ }^{8}$ In human skin Merkel cells are especially accumulated in hair discs, in the bulge region of hair follicles and in the basal layer of glabrous epidermis where they are connected to the surrounding keratinocytes by relatively few, small desmosomes. ${ }^{9,10}$ Similarly, desmosomes and desmosome-related structures have been 
observed in a subset of MCCs; however, their exact molecular composition has not yet been determined. ${ }^{11-13}$ Moreover, both in Merkel cells and in MCCs other cell adhesion proteins have been reported, among these E-cadherin (E-cad) $)^{6,14,15}$ and immunoglobulinor mucin-like cell adhesion molecules.

Changes in the repertoire of cell-cell adhesion molecules are thought to be an important prerequisite for the development and progression of several kinds of tumours. This applies especially to cadherins (cads). Cads are calcium-dependent transmembrane glycoproteins that can mediate intercellular adhesion both by homophilic and heterophilic trans-interaction and thereby establish either homotypic contacts between cells of the same type or heterotypic adhesions between different kinds of cells. ${ }^{16,17}$ Classical cads are known as transmembrane components of adherens junctions (zonulae adhaerentes) and include E-cad, regarded as typical of epithelial cells, N-cad, characteristically occurring on mesenchymal and neuronal cells, P-cad, first identified in the placenta, and cad 5 (VEcad), typically synthesized by endothelial cells. ${ }^{18}$ During the development of diverse types of carcinomas and malignant melanomas E-cad may be down-regulated and replaced by $\mathrm{N}$-cad, a phenomenon referred to as "cadherin switch" which is believed to be of great pathogenic importance. ${ }^{19,20}$ The family of desmosomal cads consists of the cell typespecific desmoglein isoforms Dsg1-4 and the desmocollins, occurring in three isoforms (Dsc1-3). ${ }^{21}$ The third group of plaque-bearing junctions are tight junctions (TJ), which comprise occludin, claudins, JAMs and tricellulin as transmembrane proteins and typically exert barrier functions. ${ }^{22,23}$ Compared to classical cads, the significance of desmosomal and TJ proteins for tumourigenesis has been less well determined. However, increasing evidence suggests that they may function as regulators of cell proliferation, differentiation, polarity and apoptosis and contribute to tumourigenic processes. ${ }^{24-26}$ 
In this study, we determined the repertoire of cell junction proteins in Merkel cells of human glabrous epidermis and in 52 different MCCs and correlated the results to clinical information and to the MCV status. (...)

\section{Materials and Methods}

\section{Patients and tumours}

Paraffin-embedded samples of MCCs which had been surgically removed between 1995 and 2008 were obtained from the Department of Pathology of the University Medical Centre Mannheim. In addition, the Department of Dermatology of the University Hospital of Würzburg provided MCC microarrays. Samples of human glabrous skin, human colon, heart tissues and pancreatic carcinomas to be used as positive and negative controls were obtained from the Institutes of Pathology of the University Medical Centre Mannheim and the University Hospital Heidelberg. Clinical data were retrieved from the patients' medical records archived in the University Medical Centre Mannheim. All procedures were performed with informed consent and according to the principles of the Declaration of Helsinki and were approved by the local Medical Ethics Committees.

\section{Antibodies}

Commercially available antibodies against the following antigens were used in this study: Murine monoclonal antibodies against $\mathrm{N}$-cad (application concentration $2.5 \mu \mathrm{g} / \mathrm{ml}$ ), E-cad (5 $\mu \mathrm{g} / \mathrm{ml})$, P-cad $(5 \mu \mathrm{g} / \mathrm{ml})$ and B-catenin ( $\beta$-cat, $2.5 \mu \mathrm{g} / \mathrm{ml}$; BD Biosciences Pharmingen, Heidelberg, Germany); $\alpha$-cat (10 $\mu \mathrm{g} / \mathrm{ml})$, Dsg3 $(10 \mu \mathrm{g} / \mathrm{ml})$, protein ZO-1 $(10 \mu \mathrm{g} / \mathrm{ml})$, claudin $4(10 \mu \mathrm{g} / \mathrm{ml}$; Invitrogen, Karlsruhe, Germany); desmoplakins 1 and 2, plakoglobin, plakophilin 1 (PKP1), PKP2, PKP3, Dsc1, Dsc3, Dsg1, Dsg1 and 2 (clone DG3.10) and Dsg3 (hybridoma supernatants, 10-15 $\mu \mathrm{g} / \mathrm{ml}$; Progen Biotechnik, Heidelberg, Germany); 
rabbit antisera against $\mathrm{N}$-cad (10 $\mu \mathrm{g} / \mathrm{ml}$; Abcam, Cambridge, United Kingdom), cad 5 (VEcad, $1 \mu \mathrm{g} / \mathrm{ml}$; Biozol Diagnostica, Eching, Germany), protein 120 (concentration of total IgG ca. $10 \mathrm{mg} / \mathrm{ml}$, diluted 1:50 for application; Sigma, Deisenhofen, Germany), Dsc2 (ca. $10 \mathrm{mg} / \mathrm{ml}$ total $\mathrm{lgG}$, diluted 1:50; Progen Biotechnik), proteins ZO-1 $(2.5 \mu \mathrm{g} / \mathrm{ml})$ and ZO-2 $(5 \mu \mathrm{g} / \mathrm{ml})$, claudin $2(10 \mu \mathrm{g} / \mathrm{ml})$, claudin $3(5 \mu \mathrm{g} / \mathrm{ml})$, claudin $5(5 \mu \mathrm{g} / \mathrm{ml})$, occludin $(5 \mu \mathrm{g} / \mathrm{ml})$ and JAM-A ( $5 \mathrm{\mu g} / \mathrm{ml}$; Invitrogen, Karlsruhe, Germany) and a goat antiserum to JAM-A (5 $\mu \mathrm{g} / \mathrm{ml}$; R \& D Systems, Wiesbaden, Germany). Guinea pig antibodies against desmoplakin and a rabbit antiserum to Dsg2, diluted 1:1000 or 1:500, respectively, were a gift from Dr. Lutz Langbein (Division of Genetics of Skin Carcinogenesis, German Cancer Research Center), murine monoclonal antibodies against PKP2 (hybridoma supernatant, $10 \mu \mathrm{g} / \mathrm{ml}$ ) were kindly provided by Steffen Rickelt (Helmholtz Group for Cell Biology, German Cancer Research Center). As markers for Merkel cells, a monoclonal antibody against CK20 (hybridoma supernatant, $10 \mu \mathrm{g} / \mathrm{ml}$ ), a guinea pig antiserum to CK20 (containing ca. 4 $\mathrm{mg} / \mathrm{ml}$ total $\mathrm{lg}$, diluted 1:500 for application) and murine monoclonal antibodies to chromogranin A (hybridoma supernatant, $10 \mu \mathrm{g} / \mathrm{ml}$; Progen Biotechnik) were used. Primary antibody complexes were visualized with secondary antibodies coupled to either Cy 2 (Abcam), Сy3 (Dianova, Hamburg, Germany) or Alexa 488 (MoBiTec, Göttingen, Germany).

\section{Immunhistochemistry and data analysis}

Paraffin-embedded tissue specimens were sectioned at $4 \mu \mathrm{m}$ thickness, dried overnight in an incubator at $37^{\circ} \mathrm{C}$ and deparaffinized according to standard techniques. Heat-induced antigen retrieval was performed in a Milestone Rapid Microwave Histoprocessor (MLS GmbH, Leutkirch im Allgäu, Germany), using several different protocols: (1) citrate buffer (82 mM sodium citrate and $18 \mathrm{mM}$ citric acid, $\mathrm{pH} 6.0$ ), $10 \mathrm{~min}$ at $120^{\circ} \mathrm{C}$; (2) citrate buffer, $30 \mathrm{~min}$ at $120^{\circ} \mathrm{C}$; (3) $100 \mathrm{mM}$ TRIS- $\mathrm{HCl}$ buffer containing $5 \%$ urea $(\mathrm{pH} 11.0), 15 \mathrm{~min}$ at 
$120^{\circ} \mathrm{C}$; (4) $100 \mathrm{mM}$ TRIS-HCl buffer plus $5 \%$ urea (pH 11.0), $30 \mathrm{~min}, 120^{\circ} \mathrm{C}$; and (5) 100 $\mathrm{mM}$ TRIS- $\mathrm{HCl}$ buffer without urea, $\mathrm{pH} 10.2,30 \mathrm{~min}, 120^{\circ} \mathrm{C}$. The optimal condition was determined separately for each antibody, using samples of human skin, colon, heart and pancreatic carcinomas as positive and negative controls. Antigen retrieval was followed by a wash in PBS, an incubation step in PBS containing $2 \%$ non-fat dry milk powder with or without $0.2 \%$ Triton $\mathrm{X}-100$ and blocking with $2 \%$ milk powder in PBS (15 min). For identification of Merkel cells or Merkel carcinoma cells, specimens were routinely doublelabelled with antibodies to cell junction proteins in combination with CK20 antibodies. Primary antibodies were applied for 1-2 $\mathrm{h}$ at room temperature, secondary antibodies for 45 minutes. After washes in PBS, a brief rinse in distilled water and dehydration in ethanol, sections were mounted with Fluoromount-G (Biozol Diagnostica). Immunfluorescence was recorded with an Axiophot II photomicroscope (Carl Zeiss, Jena, Germany) equipped with an AxioCam HR (Carl Zeiss). Samples of healthy plantar epidermis were analyzed with a Zeiss LSM 510 UV confocal laser scanning microscope. To test immunostaining results obtained for primary tumours versus $L N$ metastases for statistically significant differences, bivariate t-tests were performed.

\section{DNA isolation and MCV detection}

Genomic DNA was isolated from serial paraffin sections using a DNA Isolation Kit (Qiagen, Hilden, Germany). The samples were analyzed for the presence of MCV by using a TaqMan assay specific for the MCV large T-antigen and VP1 gene. Taqman primer and probe for large T-antigen were described previously. ${ }^{27}$ For VP1 they were designed with Primer Express (Applied Biosystems): forward GCC TTT TGA GGT CCT TTC AGT G, reverse ACT GTT TAC CCA AAG CCC TCT G and the probe FAM-CGC CTT GCC CTT ATC CTG CTG ATT ACT TTG-BHQ1. LINE1, a highly repetitive DNA element, served as DNA control. 


\section{Results}

\section{Heterotypic contacts between Merkel cells and keratinocytes in human glabrous skin}

To determine the protein composition of the heterotypic junctions connecting Merkel cells and keratinocytes, sections of human plantar epidermis were double-immunostained with antibodies to cell junction proteins and to CK20 as Merkel cell marker and analyzed by confocal laser scanning microscopy (Figure 1; Table 1). To this end, both E-cad (Figure 1a, a') and P-cad (Figure 1b, b') were clearly detectable at the heterotypic Merkel cellkeratinocyte contacts whereas other classical cads such as N-cad or VE-cad were not found at these sites (Table 1). Moreover, Merkel cell-keratinocyte junctions were strongly positive for the plaque proteins of AJ, i.e., $\alpha$-cat (not shown), $\beta$-cat (Figure 1c, c'), protein p120 and plakoglobin, a plaque component of both $\mathrm{AJ}$ and desmosomes (not shown).

When double-immunostaining and confocal laser scanning microscopy was performed for desmosomal proteins in combination with CK20, the heterotypic contacts were demonstrated to contain Dsg2 (Figure 1d, d') and Dsc2 (not shown), desmosomal cads typical of the basal epidermal layer. In contrast, Dsc3 and the desmosomal cads Dsg1 (Figure 1e, e') and Dsc1 that are synthesized in higher amounts in upper epidermal layers, appeared absent from these sites. Immunoreactivity for Dsg3 could not be unambiguously determined, as the available Dsg3 antibodies did not reliably react on paraffin under the conditions tested. Furthermore, desmosomes that connect Merkel cells and keratinocytes were positive for the plaque components desmoplakin (Figure 1f, f'), plakoglobin, PKP1 and PKP3, but not for PKP2 (not shown; for survey see Table 1).

Since human epidermis contains TJ proteins and TJ-related structures in addition to AJ and desmosomes, we stained for the transmembrane proteins occludin, claudins 1-5 and JAM-A and the plaque protein ZO-1 in human glabrous skin. ${ }^{28-30}$ The heterotypic 
adhesions between Merkel cells and keratinocytes appeared negative for all TJ components examined although immunoreactivity for JAM-A at these sites could not unambiguously be assessed (data not shown).

\section{Demographic and clinical characteristics and MCV status of patients with MCC}

In order to determine the relevance of cell adhesion proteins for the development and progression of MCC, we analyzed 52 MCCs from 32 different patients, among them 26 primary tumours, 9 recurrences, 15 LN metastases, one metastasis of the thoracic wall and one parotid gland metastasis. In Table 2, a summary of the demographic and clinical characteristics of the patients is presented. $44 \%$ of the patients were male, $56 \%$ female. The mean age at initial diagnosis was 73.7 years (range: $53-92$ years). $34 \%$ of the primary tumours were located at the head or neck, $22 \%$ each on the upper and the lower extremities and $16 \%$ on the trunk. At least $34 \%$ of the patients developed a local recurrence, at least $56 \%$ LN metastases and at least $25 \%$ other metastases.

For clinical staging, the system suggested by the German Working Group of Dermatological Oncology was applied, in which stage I includes primary tumours only, stage II locoregional metastases and stage III distant metastases. ${ }^{31}$ At initial diagnosis, $50 \%$ of the patients were in tumour stage I, $34 \%$ in stage II and one patient $(3 \%)$ in stage III. Patients were followed up for a mean duration of 23.1 months (range: $0-120$ months). At the end of the follow-up, $31 \%$ remained in stage I and $38 \%$ were in stage II whereas $19 \%$ had progressed to stage III (13\% not known).

An examination of the histological subtype revealed a predominantly trabecular pattern in $23 \%$ of the tumours, an intermediate pattern in $40 \%$ and a small cell type in $37 \%$, with several tumours displaying mixed and/or transitional patterns (Supplementary Tables S1-S3). $92.5 \%$ of the MCCs were positive for CK20 and $76 \%$ for chromogranin A (for detailed results, see Table S1). 
Real time PCR was performed to determine the MCV status of our patients, using primers specific for the T-antigen and the VP1 gene (Table 2). To this end, $83.3 \%$ of all patients or $84 \%$ of all tumours were MCV-positive with concordant results for all samples of the same patient. Patients with MCV-negative tumours appeared to be in somewhat more advanced clinical stages than the average. However, the number of cases ( $n=5$ MCV-negative patients) was too small to allow reasonable statistical correlation.

\section{Cell-cell junctions in MCCs: Components of AJ}

When MCCs were double-labelled for AJ proteins in combination with CK20, positive immunostaining for $\mathrm{N}$-cad was noted in the large majority of tumours (90.4\%; Figure 2a, a', b, b'). This result was obtained both with a monoclonal $\mathrm{N}$-cad antibody and with a rabbit antiserum directed against a different epitope of the $\mathrm{N}$-cad sequence. Moreover, almost all tumours synthesized $\alpha$ - and $\beta$-cat (Figure 2f, f') and protein p120 (Table 3). In contrast, only $67 \%$ or $65 \%$ of all MCCs were E- or P-cad-positive (Figure $2 c$, c', d, d', e, e'; Table 3). Among the E- and/or P-cad-negative MCCs 10 tumours showed loss of both E- and P-cad. 8 tumours were negative for only P-cad and 7 tumours for only E-cad (for a detailed survey of all staining results see Table S1). All AJ proteins were accumulated along cell-cell borders of the carcinoma cells, exhibiting a linear pattern, whereas the E-cad-positive nuclear staining reported by another group was not detected. ${ }^{14}$ Some tumours, e.g., especially aggressive malignant melanomas and astrocytomas, can undergo "vascular mimicry", a process facilitating hematogenic metastasis and coinciding with upregulation of VE-cad. ${ }^{32,33}$ For this reason, we also tested MCCs for VE-cad. However, this protein was not detected in any of the tumours.

To verify our results on $\mathrm{N}$-, E- and P-cad on an independent set of tumours we stained microarrays with 23 different MCCs (13 primary tumours, 1 recurrence, 2 LN metastases, 6 other metastases, 1 n. d.) with the respective antibodies (not shown). We 
found that $92 \%$ of the carcinomas synthesized $\mathrm{N}$-cad and $74 \%$ each $\mathrm{E}$ - and $\mathrm{P}$-cad, which agrees well with our own set of data.

Comparison between the cad pattern and the histological type revealed a similiar distribution of classical cads in all subtypes of MCCs, including small cell tumours, although the latter were slightly more likely to lack N-and E-cad (Table S1). No significant difference was found for tumours that were sorted according to their MCV status. Interestingly, however, $77 \%$ of the primary tumours and $78 \%$ of the recurrences, but only $33 \%$ of the LN metastases contained P-cad (Table 3). This difference between primaries and LN metastases was statistically significant, as determined by bivariate t-test ( $p=$ 0.006). To verify whether occurrence of P-cad in primary tumours might have any prognostic implications, patients with P-cad-positive and -negative primary tumours were compared with regard to their clinical stage. Indeed, patients with P-cad-negative primaries appeared to be in a more advanced stage at initial diagnosis and at the end of the followup, both in comparison to those with P-cad-positive primaries and in comparison to all primary MCCs (Table 4). However, the small number of P-cad-negative primary tumours $(n=6)$ did not allow informative statistical analyses.

\section{Repertoire of desmosomal proteins in MCCs}

Analysis of desmosomal proteins revealed Dsg2 as the most frequent transmembrane constituent, present in $62 \%$ of all MCCs (Figure 3a, a'), whereas other desmosomal cads were rare (Table 5; for examples of Dsg1- and Dsc1-negative tumours, see Figure 3b, b', c, c'). Interestingly, antibodies to Dsg2 reacted in a punctuate pattern typical of desmosomes only in a subset of Dsg2-positive tumours (66\%). In another subtype, linear staining along cell boundaries was noted, an observation made with two different Dsg2 antibodies (see also Table S2 in Supplementary Materials). MCCs exhibiting Dsg2-positive punctuate staining nearly always contained desmoplakin as desmosomal plaque protein 
(Figure 3d, d', e, e'), while the majority of tumours with linear Dsg2 immunofluorescence was desmoplakin-negative. In the latter subgroup, the repertoire of desmosomal plaque proteins was variable, comprising plakoglobin and/or plakophilin (PKP) 1, 2 and 3 (Table 5; for detailed results, see Table S2). An example of a PKP1-positive primary carcinoma, displaying rather diffuse immunolabel concentrated along cell borders, is presented in Figure $3 f$ and f'.

When the subgroups of tumours were compared, it was remarkable that desmoplakin-positive punctuate immunolabel occurred significantly more frequently in LN metastases than in primary carcinomas $(p=0.003)$. However, there was no correlation between the patterns of desmosomal proteins in primary tumours and the clinical stage (data not shown). Moreover, no correlations to the histological subtype or the MCV status were found.

\section{Detection of tight junction proteins}

A surprising observation made in this study was the detection of $\mathrm{TJ}$ proteins in a large proportion of MCCs (Figure 4, Table 6). The transmembrane components observed most frequently were occludin, present in $59 \%$ of all tumours (Figure $4 a$, a'), claudin 3 (63\%, Figure 4b, b'), claudin 5 (86\%, Figure 4c, c') and JAM-A (60\%; Figure 4d, d'), Moreover, smaller subsets of tumours were positive for claudins 1 and 4 (Table 6). The vast majority of tumours contained two or more TJ transmembrane proteins simultaneously, mostly in association with protein ZO-1 and/or protein ZO-2 as plaque component (Figure 4e, e', f, f'; for survey of all results see Table S3). Markedly positive linear immunostaining at cell-cell junctions was observed with all antibodies against TJ proteins (Figure 4a-f, a'-f'). However, especially with occludin antibodies, immunofluorescence sometimes appeared more diffuse than in colonic tissues that were used as controls. 
When the patterns of $\mathrm{TJ}$ proteins were correlated with the histological type, TJ transmembrane and plaque proteins were detected in all subtypes of MCCs but were slightly less frequent in small cell tumours (Table S3). Comparison between TJ proteins in primary tumours and the clinical stage gave no obvious associations, with the exception that protein ZO-2 tended to be absent more frequently in more advanced stages (data not shown). Furthermore, the repertoire of TJ components appeared to be independent of the presence of MCV.

\section{Discussion}

\section{Heterotypic contacts between Merkel cells and keratinocytes}

(...) According to our confocal laser scanning microscopic analyses heterotypic Merkel cell-keratinocyte adhesions comprise not only the ensemble of desmosomal proteins typical of basal keratinocytes (perhaps with the exception of PKP 2), but also the complete repertoire of epithelial AJ proteins, i.e., E- and P-cad, $\alpha$ - and $\beta$-cat, protein p120 and plakoglobin. Previous ultrastructural examinations have revealed small desmosomes between Merkel cells and keratinocytes, whereas other types of plaque-bearing junctions have not yet been described at these sites. ${ }^{6,7,9,10}$ To elucidate the morphological correlate of the E- and P-cad-positive heterotypic junctions, electron and immunoelectron microscopic investigations are required. In this context, we have recently demonstrated small E- and P-cad-containing "puncta adhaerentia" connecting keratinocytes and melanocytes. ${ }^{34}$ Alternatively, the plaque-bearing junctions between Merkel cells and keratinocytes referred to as desmosomes might in fact represent "hybrid" junctions, comprising both desmosomal and AJ components, as detected in diverse other cell types. $^{35-37}(\ldots)$ 


\section{Cadherin switch in MCC}

A remarkable result of our study is that almost all MCCs (> 90\%) contained $\mathrm{N}$-cad, whereas Merkel cells of healthy epidermis were N-cad-negative. In contrast, E- and P-cad antibodies reacted only in a subset of MCCs but strongly and consistently labelled Merkel cells. Classical cads have been studied in smaller MCC samples, comprising 35 or 31 tumours, respectively, by two other groups. ${ }^{14,15}$ Tanaka and colleagues have found E-cadpositive immunoreactions along cell membranes in $70 \%$ of the MCCs examined, appearing markedly weaker than in normal human epidermis, well in accordance with our data. ${ }^{15}$ In the study by Han and coworkers, $97 \%$ of the MCCs showed E-cad immunolabel. ${ }^{14}$ However, the protein was concentrated at cell boundaries in only $57 \%$ of the tumours, whereas $91 \%$ displayed E-cad-positive staining in the nucleus, either exclusively or in addition to membrane staining. We did not detect nuclear E-cad staining in any of our MCCs, possibly due to differences in tissue fixation or in the protocols for antigen retrieval and immunostaining. Moreover, this group reported $\mathrm{N}$-cad in $63 \%$ and $\mathrm{P}$-cad in $43 \%$ of the MCCs, both concentrated at cell membranes. ${ }^{14}$ Our observations, obtained on two independent sets of MCCs and with two different $\mathrm{N}$-cad antibodies, suggest that MCCs in fact contain $\mathrm{N}$-cad more frequently.

Despite extensive research, the origin of MCCs has still not been clarified. A controversy exists about whether they are derived from pluripotent cutaneous stem cells or from Merkel cells, as reflected by their designation. Observations favouring a stem cell origin are that MCCs and MCC-derived cell culture lines express neurofilament proteins and transcription factors typical of neuronal crest cells. ${ }^{38,39}$ However, subgroups of normal Merkel cells may also synthesize neuronal proteins. ${ }^{40,41}$ On the other hand, there are strong arguments in support of the notion that MCCs are derived from Merkel cells: First, MCCs consistently synthesize the cytokeratin characteristic of Merkel cells, CK20.,42 
Second, Merkel cells and MCCs share a neuroendocrine phenotype and neuroendocrine markers, such as chromogranin A and synaptophysin. ${ }^{3,43-45}$

Assuming that MCCs emerge from Merkel cells, our results indicate that during their tumourigenesis a "cadherin switch" takes place. This term usually refers to a shift from the expression of $\mathrm{E}$ - to $\mathrm{N}$-cad, noted in several types of carcinomas. It also includes situations in which cells continue to synthesize E-cad but additionally turn on or increase the expression of $\mathrm{N}$-cad, as noted in most of our tumours. ${ }^{20}$ Expression and amounts of $\mathrm{E}$ - and $\mathrm{N}$-cad can influence the behaviour of cells in several ways: (1) by affecting $\beta$-cat translocation to the nucleus during Wnt signalling; (2) by modulating growth factor receptor-dependent signalling pathways; (3) by activating small GTPases that promote cell migration and invasion; (4) by affecting cell polarity; and (5) by suppressing apoptotic pathways. ${ }^{19,20} \mathrm{~N}$-cad provides the tumour cells with a new adhesive repertoire to interact with new, mostly mesenchymal neighbors such as fibroblasts, blood vessels and lymphatic tissues, facilitating invasion and migration during metastasis. ${ }^{46,47}$ Moreover, this cad can promote cell motility, invasion and survival, hereby also overriding E-cad signalling. ${ }^{20,46,47}$ In contrast, E-cad can serve as a suppressor of invasion and metastasis in many contexts. $^{19,48,49}$

P-cad has been implicated in tumourigenesis as well; however, its impact appears to be variable, depending on the specific type of cancer. On one hand, it has been established as an indicator of poor prognosis in breast carcinomas. ${ }^{50}$ On the other hand, in malignant melanomas P-cad promotes adhesion and counteracts migration, and membranous P-cad staining has been correlated with a favourable prognosis. ${ }^{51,52}$ Our findings that (1) P-cad was significantly more frequent in primary MCCs than in LN metastases and (2) patients with P-cad-negative primary tumours tended to be in more advanced clinical stages might be interpreted as clues for a beneficial role of P-cad, a 
hypothesis that will have to be verified both by functional studies and by larger-scale in situ-investigations.

Our study dealt only with few organ metastases, i.e., one metastasis of the thoracic wall and one of the parotid gland and 6 filiae contained in the microarrays. Yet, 7 of these 8 metastases stained positive for both E-cad and P-cad (data not shown), in discrepancy with the observation that only $33 \%$ of the LN metastases comprised P-cad. Clearly, due to the small number of cases the significance of this observation is limited. However, it may be possible that in MCCs P-cad is only temporarily decreased during certain steps of tumour cell segregation and invasion and then is re-expressed in the advanced metastatic tumour. Development of certain epithelial tumours coincides with an "epithelial to mesenchymal transition" (EMT), during which epithelial cell adhesion molecules are replaced by those typical of mesenchymal cells. ${ }^{53}$ Conversely, during formation of distant metastases, a reverse phenomenon, referred to as "mesenchymal to epithelial reverting transition" (MErT), can occur which is accompanied by re-expression of epithelial adhesion molecules and thereby thought to facilitate adherence and settlement of metastatic cells. ${ }^{54}$

\section{Desmosomal proteins in a subset of MCCs}

While Merkel cells of normal human epidermis appear to consistently form desmosomes containing both Dsc2 and Dsg2, desmosomal proteins have been detected only in a subset of our MCCs. The desmosomal cad noted most frequently was Dsg2, occurring in more than $60 \%$ of the tumours, whereas other desmosomal cads were rare. As desmosomes obligatorily comprise at least one desmoglein and one desmocollin and both are required for adhesion, it is especially surprising that Dsc2 was so uncommon. However, it is possible that the amounts of Dsc2 in MCCs were too low to be detected by our antibodies and with the staining protocols applied. 
Remarkably, Dsg2- and desmoplakin-positive punctuate immunostaining patterns typical of desmosomes were observed only in two thirds of the Dsg2-containing MCCs. As desmoplakin is known to be mandatory for desmosomal adhesion, only the subgroup of tumours that are positive for both Dsg2 and desmoplakin may form true desmosomes or desmosome-related structures, as seen by electron microscopy in a subset of MCCs. ${ }^{11-13}$ Interestingly, these putative desmosomes were found more frequently in LN metastases than in primary tumours, alluding to a role in adhesion during lymphogenic dissemination.

In another subgroup of Dsg2-positive MCCs the protein was accumulated along cell borders in a linear pattern, together with plakoglobin and/or PKPs, but not with desmoplakin. The structure of these linear Dsg2-positive adhesions will have to be elucidated by electron and immunoelectron microscopy. It is conceivable that they represent "hybrid junctions" in which the desmosomal components occur together with AJ proteins. Interestingly, linear cell border localization of Dsg2 has also been noticed in certain melanoma and fibrosarcoma cell lines and in malignant melanomas. Here the protein appears as a solitary cell surface component, possibly constituting the basis of a novel, primitive adhesive system. ${ }^{34,55,56}$

The impact of desmosomal proteins on tumourigenesis is by far less well understood than that of classical cads and AJ-associated plaque proteins. Yet, many reports have documented alterations in their patterns during carcinogenesis, well in line with our results in MCCs. Depending on the specific kind of tumour, desmosomal cads may be both up- or down-regulated. For example, Dsg2 is reduced and abnormally distributed in certain gastric carcinomas but appears increased in cutaneous squamous cell carcinomas and in prostate carcinoma cell lines with high metastatic potential. ${ }^{57-59}$ Ectopic expression of Dsg2 in suprabasal keratinocytes leads to hyperproliferation of the epidermis and development of skin tumours. ${ }^{60}$ Moreover, Dsg2 has recently been suggested to act as a regulator of apoptosis..$^{60,61}$ 
Rearrangements of desmosomal cads during tumourigenesis are believed to result in a release of plakoglobin from the desmosomal plaque, leading to displacement of $\beta$-cat from $\mathrm{AJ}$, translocation to the nucleus and activation of Wnt signalling. ${ }^{24}$ On the other hand, plakoglobin itself has also been reported to induce both pro- and anti-proliferative cascades, depending on the cellular context. Moreover, other components of the desmosomal plaque, i.e., desmoplakin and PKPs, might be able to influence Wnt signalling, although the underlying mechanisms have not yet been well defined.

\section{Occurrence of $\mathrm{TJ}$ proteins and possible implications}

An unexpected result of our study is that a large proportion of MCCs contain TJ proteins. Occurrence of TJ components in MCCs has been described in a book chapter by Haass and colleagues, but their pattern, subcellular distribution and frequency have not been examined so far. ${ }^{62}$ Recently, alterations in the levels of TJ proteins have been reported for several other types of tumours..$^{22,25,26}$ For example, expression levels of claudins can be significantly up- or down-regulated during tumourigenesis. Depending on the specific kind of cancer, the same type of claudin may be either increased or decreased, as demonstrated for claudins 1, 2, 4 and 5. In contrast, claudin 3 seems to be preferentially augmented.

Most remarkably, a high percentage of our MCCs were positive for claudin 5 , a TJ transmembrane protein typically synthesized in endothelial cells of blood and lymphatic vessels but also reported to occur in the granular epidermal layer. ${ }^{63-66}$ It can be speculated that this claudin might promote interactions of the Merkel carcinoma cells with endothelia, thus facilitating hematogenic and lymphogenic metastasis. A large number of MCCs also displayed positive immunostaining for claudin 3, a receptor for Clostridium perfringens enterotoxin (CPE) which normally occurs in the gastrointestinal tract, in liver, kidney and pancreas. ${ }^{67}$ Interestingly, controlled administration of CPE has been suggested as a novel 
strategy for cancer treatment, also implying therapeutic perspectives for MCCs with marked claudin 3 accumulation..$^{25,68}(\ldots)$

The molecular mechanisms underlying the differential regulation of TJ components in tumours are only beginning to be elucidated. Yet, there is increasing evidence that these proteins can contribute to the regulation of cell proliferation, survival, differentiation and gene expression, e.g. by interplays with tumour suppressors and transcription factors. ${ }^{24,25}$ Moreover, certain claudins have been shown to promote tumour cell invasion and migration by interacting with matrix metalloproteinases and by triggering structural and functional changes in markers of EMT. ${ }^{69}$

Clearly, it will be interesting to determine the ultrastructural correlate of the TJ proteins in MCCs, especially as such proteins may also occur outside of typical zonulae occludentes, e.g., at "lamellated TJ" and "sandwich junctions" within the epidermis or at cell-cell bridges of retothelial lymphatic cells. ${ }^{29,65}$ Furthermore, functional studies are required to determine whether the TJ proteins of MCCs are involved in "fence" and "barrier" functions. E.g., it appears possible that the formation of TJ in MCCs might constitute a mechanism of self-isolation of the tumour cells from the microenvironment. This could also contribute to the well-known phenomenon that MCCs rapidly develop resistance to chemotherapeutic agents after initial response.

\section{Detection of MCV}

MCV was detected in $84 \%$ of our MCC samples or in $83 \%$ of the patients, respectively. This observation corresponds well with other European and Northern American reports, according to which $69-85 \%$ of the MCCs are MCV-positive. $5,27,70,71$ A causal role of MCV for the development of MCC has not yet been proven. However, this notion is supported by several lines of evidence..$^{5,70,72,73}$ (...) Most importantly, the MCV DNA is integrated into the tumour tissues in a clonal - mostly monoclonal - fashion. ${ }^{5}$ Primary tumours and their 
metastases show identical integration patterns, implicating that viral infection precedes metastasis formation. ${ }^{5,72}$ This also agrees with our finding that in the primary MCC and the metastases of the same patient the MCV status was always concordant. (...)

Whether MCV has any impact on clinical outcome of MCC patients is a matter of intense ongoing research. Our patients with MCV-negative tumours appeared to be in more advanced stages than average. Correspondingly, two other groups reported a favorable clinical course for MCV-positive MCCs or for MCCs with higher abundance of MCV DNA. ${ }^{74,75}$

Assuming that MCCs originate from Merkel cells, our data indicate a switch from Eand $\mathrm{P}$ - to $\mathrm{N}$-cad and de novo synthesis of $\mathrm{TJ}$ proteins during tumourigenesis. In the present study we did not find any obvious correlation between the patterns of cell junction proteins and the MCV status. However, definite assessment of this question will require examination of a larger number of cases.

\section{Conflict of interest}

The authors declare no conflict of interest.

List of abbeviations: cad - cadherin; cat - catenin; Dsc - desmocollin; Dsg desmoglein; DP - desmoplakin; LN - lymph node; mab - monoclonal antibody; MCC Merkel cell carcinoma; MCV - Merkel cell virus; PKP - plakophilin 


\section{Acknowledgements}

The authors thank Prof. Dr. Alexander Marx (Institute of Pathology, University Medical Centre Mannheim) and Dr. Beate Straub (Institute of Pathology, University of Heidelberg) for furnishing tumour material and Prof. Dr. Frederik Wenz (Department of Radiation Oncology, University Medical Centre Mannheim) for providing clinical information. EvaMaria Stuhl (Department of Dermatology, University of Würzburg) is acknowledged for excellent technical assistance. In addition, we thank Prof. Dr. Werner W. Franke (Hemholtz Group for Cell Biology, German Cancer Research Center) for helpful discussions and critical reading of the manuscript and Dr. Alexander Ludwig (Mannheim Institute for Economics of Aging, Mannheim) for help with statistical analyses. This work was supported by grants from the Deutsche Krebshilfe to WKP (project no. 108626), the Johann und Anny Thomas Stiftung to JB and the Wilhelm Sander-Stiftung to JCB (project no. 2007.057.1). 


\section{References}

1. Tai P. Merkel cell cancer: update on biology and treatment. Curr. Opin. Oncol. 2008; 20; $196-200$.

2. Moll R, Löwe A, Laufer J, Franke WW. Cytokeratin 20 in human carcinomas. A new histodiagnostic marker detected by monoclonal antibodies. Am. J. Pathol. 1992; 140; 427-447.

3. Visscher D, Cooper PH, Zarbo RJ, Crissman JD. Cutaneous neuroendocrine (Merkel cell) carcinoma: an immunophenotypic, clinicopathologic, and flow cytometric study. Mod. Pathol. 1989; 2; 331-338.

4. Becker JC, Schrama D, Houben R. Merkel cell carcinoma. Cell. Mol. Life Sci. 2009; $66 ; 1-8$.

5. Feng $H$, Shuda $M$, Chang $Y$, Moore PS. Clonal integration of a polyomavirus in human Merkel cell carcinoma. Science 2008; 319; 1096-1100.

6. Moll I, Roessler M, Brandner JM, Eispert AC, Houdek P, Moll R. Human Merkel cells aspects of cell biology, distribution and functions. Eur. J. Cell Biol. 2005; 84; 259-271.

7. Lucarz A, Brand G. Current considerations about Merkel cells. Eur. J. Cell Biol. 2007; 86; 243-251.

8. Van Keymeulen A, Mascre G, Youseff KK et al. Epidermal progenitors give rise to Merkel cells during embryonic development and adult homeostasis. J. Cell Biol. 2009; 187; 91-100.

9. Hashimoto K. The ultrastructure of the skin of human embryos. X. Merkel tactile cells in the finger and nail. J. Anat. 1972; 111; 99-120.

10. Hartschuh W, Weihe E, Yanaihara N. The Merkel cell. In Bereiter-Hahn J, Matoltssy AG, Richards KS eds. Biology of the Integument, Vol. 2. Berlin, Heidelberg, New York: Springer, 1986; 606-620.

11. Warner TF, Uno H, Hafez GR et al. Merkel cells and Merkel cell tumours. Ultrastructure, immunocytochemistry and review of the literature. Cancer 1983; 52; 238-245.

12. Moll R, Osborn M, Hartschuh W, Moll I, Mahrle G, Weber K. Variability of expression and arrangement of cytokeratin and neurofilaments in cutaneous neuroendocrine carcinomas (Merkel cell tumours): immunocytochemical and biochemical analysis of twelve cases. Ultrastruct. Pathol. 1986; 10; 473-495.

13. Sidhu GS, Chandra P, Cassai ND. Merkel cells, normal and neoplastic: an update. Ultrastruct. Pathol. 2005; 29; 287-294.

14. Han AC, Soler AP, Tang CK, Knudsen KA, Salazar H. Nuclear localization of Ecadherin expression in Merkel cell carcinoma. Arch. Pathol. Lab. Med. 2000; 124; 1147-1151. 
15. Tanaka Y, Sano T, Qian ZR, Hirokawa M. Expression of adhesion molecules and cytokeratin 20 in merkel cell carcinomas. Endocr. Pathol. 2004; 15; 117-129.

16. Foty RA, Steinberg MS. The differential adhesion hypothesis: a direct evaluation. Dev. Biol. 2005; 278; 255-263.

17. Katsamba $\mathrm{P}$, Carroll $\mathrm{K}$, Ahlsen $\mathrm{G}$ et al. Linking molecular affinity and cellular specificity in cadherin-mediated adhesion. Proc. Natl. Acad. Sci. USA 2009; 106; 11594-11599.

18. Niessen CM, Gottardi CJ. Molecular components of the adherens junction. Biochim. Biophys. Acta 2008; 1778; 562-571.

19. Jeanes A, Gottardi CJ, Yap AS. Cadherins and cancer: how does cadherin dysfunction promote tumour progression? Oncogene 2008; 27; 6920-6929.

20. Wheelock MJ, Shintani Y, Maeda M, Fukumoto Y, Johnson KR. Cadherin switching. J. Cell. Sci. 2008; 121; 727-735.

21. Green KJ, Simpson CL. Desmosomes: new perspectives on a classic. J. Invest. Dermatol. 2007; 127; 2499-24515.

22. Tsukita S, Yamazaki Y, Katsuno T, Tamura A, Tsukita S. Tight junction-based epithelial microenvironment and cell proliferation. Oncogene 2008; 27; 6930-6938.

23. Balda MS, Matter K. Tight junctions and the regulation of gene expression. Biochim. Biophys. Acta 2009; 1788; 761-767.

24. Chidgey M, Dawson C. Desmosomes: a role in cancer? Br. J. Cancer 2007; 96; 1783-1787.

25. González-Mariscal L, Lechuga S, Garay E. Role of tight junctions in cell proliferation and cancer. Prog. Histochem. Cytochem. 2007; 42; 1-57.

26. Oliveira SS, Morgado-Díaz JA. Claudins: multifunctional players in epithelial tight junctions and their role in cancer. Cell. Mol. Life Sci. 2007; 64; 17-28.

27. Becker JC, Houben R, Ugurel S, Trefzer U, Pföhler C, Schrama D. MC polyomavirus is frequently present in Merkel cell carcinoma of European patients. J. Invest. Dermatol. 2009; 129; 248-250.

28. Brandner JM, Kief S, Grund $\mathrm{C}$ et al. Organization and formation of the tight junction system in human epidermis and cultured keratinocytes. Eur. J. Cell Biol. 2002; 81; 253-263.

29. Langbein L, Grund C, Kuhn C et al. Tight junctions and compositionally related junctional structures in mammalian stratified epithelia and cell cultures derived therefrom. Eur. J. Cell Biol. 2002; 81; 419-435.

30. Brandner JM. Tight junctions and tight junction proteins in mammalian epidermis. Eur. J. Pharm. Biopharm. 2009; 72; 289-294. 
31. Becker J, Mauch C, Kortmann RD et al. Short German guidelines: Merkel cell carcinoma. J. Dtsch. Dermatol. Ges. 2008; 6; Suppl 1, S15-16.

32. Hendrix MJ, Seftor EA, Hess AR, Seftor RE. Vasculogenic mimicry and tumour-cell plasticity: lessons from melanoma. Nat. Rev. Cancer 2003; 3; 411-421.

33. Boda-Heggemann J, Régnier-Vigouroux A, Franke WW. Beyond vessels: occurrence and regional clustering of vascular endothelial (VE-)cadherin-containing junctions in non-endothelial cells. Cell Tissue Res. 2009; 335; 49-65.

34. Rickelt S, Franke WW, Doerflinger Y, Goerdt S, Brandner JM, Peitsch WK. Subtypes of melanocytes and melanoma cells distinguished by their intercellular contacts: heterotypic adherens junctions, adhesive associations, and dispersed desmoglein 2 glycoproteins. Cell Tissue Res. 2008; 334; 401-422.

35. Schmelz M, Franke WW. Complexus adhaerentes, a new group of desmoplakincontaining junctions in endothelial cells: the syndesmos connecting retothelial cells of lymph nodes. Eur. J. Cell Biol. 1993; 61; 274-289.

36. Franke WW, Borrmann CM, Grund C, Pieperhoff S. The area composita of adhering junctions connecting heart muscle cells of vertebrates. I. Molecular definition in intercalated disks of cardiomyocytes by immunoelectron microscopy of desmosomal proteins. Eur. J. Cell Biol. 2006; 85; 69-82.

37. Straub BK, Boda J, Kuhn C et al. A novel cell-cell junction system: the cortex adhaerens mosaic of lens fiber cells. J. Cell Sci. 2003; 116; 4985-4995.

38. Hoefler H, Kerl H, Rauch HJ, Denk H. New immunocytochemical observations with diagnostic significance in cutaneous neuroendocrine carcinoma. $A m . J$. Dermatopathol. 1984; 6; 525-530.

39. Leonard $\mathrm{JH}$, Cook $\mathrm{AL}$, Van Gele $\mathrm{M}$ et al. Proneural and proneuroendocrine transcription factor expression in cutaneous mechanoreceptor (Merkel) cells and Merkel cell carcinoma. Int. J. Cancer 2002; 101; 103-110.

40. Gallego R, García-Caballero T, Fraga M, Beiras A, Forteza J. Neural cell adhesion molecule immunoreactivity in Merkel cells and Merkel cell tumours. Virchows Arch. 1995; 426; 317-321.

41. Eispert AC, Fuchs F, Brandner JM, Houdek P, Wladykowski E, Moll I. Evidence for distinct populations of human Merkel cells. Histochem. Cell Biol. 2009; 132; 83-93.

42. Moll I, Kuhn C, Moll R. Cytokeratin 20 is a general marker of cutaneous Merkel cells while certain neuronal proteins are absent. J. Invest. Dermatol. 1995; 104; 910-915.

43. Hartschuh W, Weihe E, Egner U. Chromogranin A in the mammalian Merkel cell: cellular and subcellular distribution. J. Invest. Dermatol. 1989; 93; 641-618.

44. Miettinen M. Synaptophysin and neurofilament proteins as markers for neuroendocrine tumours. Arch. Pathol. Lab. Med. 1987; 111; 813-818. 
45. Ortonne JP, Petchot-Bacque JP, Verrando P, Pisani A, Pautrat G, Bernerd F. Normal Merkel cells express a synaptophysin-like immunoreactivity. Dermatologica 1988; 177; 1-10.

46. Li G, Satyamoorthy K, Herlyn M. N-cadherin-mediated intercellular interactions promote survival and migration of melanoma cells. Cancer Res. 2001; 61; 38193825.

47. Qi J, Chen N, Wang J, Siu CH. Transendothelial migration of melanoma cells involves $\mathrm{N}$-cadherin-mediated adhesion and activation of the beta-catenin signaling pathway. Mol. Biol. Cell 2005; 16; 4386-4397.

48. Perl AK, Wilgenbus $P$, Dahl U, Semb H, Christofori G. A causal role for E-cadherin in the transition from adenoma to carcinoma. Nature 1998; 392; 190-193.

49. van Roy F, Berx G. The cell-cell adhesion molecule E-cadherin. Cell. Mol. Life Sci. $2008 ; 65 ; 3756-3788$.

50. Paredes J, Correia AL, Ribeiro AS, Albergaria A, Milanezi F, Schmitt FC. P-cadherin expression in breast cancer: a review. Breast Cancer Res 2007; 9; 214.

51. Van Marck V, Stove C, Van Den Bossche K et al. P-cadherin promotes cell-cell adhesion and counteracts invasion in human melanoma. Cancer Res. 2005; 65; 8774-8783.

52. Bauer R, Wild PJ, Meyer S et al. Prognostic relevance of P-cadherin expression in melanocytic skin tumours analysed by high-throughput tissue microarrays. J. Clin. Pathol. 2006; 59; 699-705.

53. Yilmaz M, Christofori G. EMT, the cytoskeleton, and cancer cell invasion. Cancer Metastasis Rev. 2009; 28; 15-33.

54. Wells A, Yates C, Shepard CR. E-cadherin as an indicator of mesenchymal to epithelial reverting transitions during the metastatic seeding of disseminated carcinomas. Clin. Exp. Metastasis 2008; 25; 621-628.

55. Chitaev NA, Troyanovsky SM. Direct Ca2+-dependent heterophilic interaction between desmosomal cadherins, desmoglein and desmocollin, contributes to cell-cell adhesion. J. Cell Biol. 1997; 138; 193-201.

56. Schmitt CJ, Franke WW, Goerdt S, Falkowska-Hansen B, Rickelt S, Peitsch WK. Homo- and heterotypic cell contacts in malignant melanoma cells and desmoglein 2 as a novel solitary surface glycoprotein. J. Invest. Dermatol. 2007; 127; 2191-2206.

57. Biedermann $\mathrm{K}$, Vogelsang $\mathrm{H}$, Becker I et al. Desmoglein 2 is expressed abnormally rather than mutated in familial and sporadic gastric cancer. J. Pathol. 2005; 207; 199206.

58. Kurzen $\mathrm{H}$, Münzing I, Hartschuh W. Expression of desmosomal proteins in squamous cell carcinomas of the skin. J. Cutan. Pathol. 2003; 30; 621-630. 
59. Trojan L, Schaaf A, Steidler A et al. Identification of metastasis-associated genes in prostate cancer by genetic profiling of human prostate cancer cell lines. Anticancer Res. 2005; 25; 183-191.

60. Brennan D, Hu Y, Joubeh $\mathrm{S}$ et al. Suprabasal Dsg2 expression in transgenic mouse skin confers a hyperproliferative and apoptosis-resistant phenotype to keratinocytes. J. Cell Sci. 2007; 120; 758-771.

61. Nava P, Laukoetter MG, Hopkins AM et al. Desmoglein-2: a novel regulator of apoptosis in the intestinal epithelium. Mol. Biol. Cell 2007; 18; 4565-4578.

62. Haass NK, Houdek P, Brandner JM, Moll I. Expression patterns of tight junction proteins in Merkel cell carcinoma. In Baumann KI, Halata Z, Moll I eds. The Merkel cell. Berlin, Heidelberg, New York: Springer, 2003; 223-226.

63. Morita K, Sasaki H, Furuse M, Tsukita S. Endothelial claudin: claudin-5/TMVCF constitutes tight junction strands in endothelial cells. J. Cell Biol. 1999; 147; 185-194.

64. Baluk P, Fuxe J, Hashizume $\mathrm{H}$ et al. Functionally specialized junctions between endothelial cells of lymphatic vessels. J. Exp. Med. 2007; 204; 2349-2362.

65. Moll R, Sievers E, Hämmerling B et al. Endothelial and virgultar cell formations in the mammalian lymph node sinus: endothelial differentiation morphotypes characterized by a special kind of junction (complexus adhaerens). Cell Tissue Res. 2009; 335; 109-141.

66. Peltonen S, Riehokainen J, Pummi K, Peltonen J. Tight junction components occludin, ZO-1, and claudin-1, -4 and -5 in active and healing psoriasis. Br. J. Dermatol. 2007; 156; 466-472.

67. Morita K, Furuse M, Fujimoto K, Tsukita S. Claudin multigene family encoding fourtransmembrane domain protein components of tight junction strands. Proc. Natl. Acad. Sci. USA 1999; 96; 511-516.

68. Kominsky SL. Claudins: emerging targets for cancer therapy. Expert Rev. Mol. Med. $2006 ; 8 ; 1-11$.

69. Agarwal R, D'Souza T, Morin PJ. Claudin-3 and claudin-4 expression in ovarian epithelial cells enhances invasion and is associated with increased matrix metalloproteinase-2 activity. Cancer Res. 2005; 65; 7378-7385.

70. Kassem A, Schöpflin A, Diaz C et al. Frequent detection of Merkel cell polyomavirus in human Merkel cell carcinomas and identification of a unique deletion in the VP1 gene. Cancer Res. 2008; 68; 5009-5013.

71. Garneski KM, Warcola AH, Feng Q, Kiviat NB, Leonard JH, Nghiem P. Merkel cell polyomavirus is more frequently present in North American than Australian Merkel cell carcinoma tumours. J. Invest. Dermatol. 2009; 129; 246-248.

72. Sastre-Garau X, Peter M, Avril MF et al. Merkel cell carcinoma of the skin: pathological and molecular evidence for a causative role of MCV in oncogenesis. $J$. Pathol. 2009; 218; 48-56. 
73. Shuda M, Feng H, Kwun HJ, Rosen ST, Gjoerup O, Moore PS, Chang Y. T antigen mutations are a human tumour-specific signature for Merkel cell polyomavirus. Proc. Natl. Acad. Sci. USA 2008; 105; 16272-16277.

74. Bhatia K, Goedert JJ, Modali R, Preiss L, Ayers LW. Merkel cell carcinoma subgroups by merkel cell polyomavirus DNA relative abundance and oncogene expression. Int. J. Cancer 23 June 2009, Epub ahead of print

75. Sihto H, Kukko H, Koljonen V, Sankila R, Böhling $T$, Joensuu $H$. Clinical factors associated with Merkel cell polyomavirus infection in Merkel cell carcinoma. J. Natl. Cancer Inst. 2009; 101; 938-945. 


\section{Figure Legends}

Figure 1. Double-label confocal laser scanning microscopy of paraffin sections from human plantar epidermis. Sections were double immunostained for CK20 as Merkel cell marker (green in a-f) in combination with antibodies to AJ (red in a-c, a'-c') and desmosomal proteins (red in d-f, d'-f'). Both E-cad (red in a, a'), P-cad (red in b, b') and $\beta$ cat (red in c, c') are seen at intercellular junctions of keratinocytes, but also at heterotypic contacts between keratinocytes and Merkel cells (asterisks). Antibodies to Dsg2 react in the basal epidermal layer, showing the punctuate pattern typical of desmosomes, both at homotypic keratinocyte and at heterotypic keratinocyte-Merkel cell adhesions (red in d, d'). In contrast, Dsg1, predominantly found in upper layers of the epidermis, is absent from Merkel cells (red in e, e'). Desmoplakin (Dp)-positive immunostaining is observed at desmosomes between keratinocytes but also at those connecting keratinocytes with Merkel cells (red in f, f'). (a"-f') phase contrast images. Bars, $20 \mu \mathrm{m}$.

Figure 2. Paraffin sections of MCCs double-labeled for classical cads (red in a-e, a'-e') or $\beta$-cat (red in $f, f^{\prime}$ ) together with CK20 (green in a-f, a"'-f'). (a-b') N-cad-positive primary tumour and $\mathrm{N}$-cad containing lymph node metastasis, showing intense $\mathrm{N}$-cad label along cell-cell contacts (red in a, a', b, b'). (c-d') Examples of an E-cad-positive (c, c') and an Ecad-negative (d, d') primary tumour. (e, e') Recurrent tumour presenting prominent P-cad label at cell boundaries. (f, f') $\beta$-cat positive reaction in a primary carcinoma. (a"'-f'”) phase contrast images. Bars, $50 \mu \mathrm{m}$.

Figure 3. MCCs immunoreacted with antibodies to desmosomal proteins (red in a-f, a'-f') and to CK20 (green in a-f, a"'-'). (a) Primary tumour showing prominent Dsg2 staining, mostly at punctuate structures typical of desmosomes. (b, c) Examples of a recurrent tumour negative for Dsg1 (red in b, b') and a primary carcinoma lacking Dsc1 (red in c, c'). 
(d-f) Tumours synthesizing desmosomal plaque proteins, i.e., a primary carcinoma (d-d'”) and a LN metastasis (e-e'") strongly positive for Dp (red in d, d', e, e') and a primary tumour containing PKP1 (red in $\mathrm{f}, \mathrm{f}^{\prime}$ ). Note that PKP1 antibodies do not display the typical desmosomal pattern but more diffuse concentrations along cell borders. (a"'-f'”) phase contrasts. Bars, $50 \mu \mathrm{m}$.

Figure 4. Double-label immunofluorescence microscopy of MCCs reacted with antibodies to TJ proteins (red in a-f, a'-f') and CK20 (green in a-f, a"-f'). Both transmembrane proteins, i.e., occludin (red in a, a'), claudin 3 (red in b, b'), claudin 5 (red in c, c') and JAMA (red in d, d'), and the TJ-associated plaque proteins ZO-1 (red in e, e') and ZO-2 (red in $\left.f, f^{\prime}\right)$, are prominent at cell borders of the carcinoma cells, exhibiting linear patterns. (a-a"') primary tumour, (b-e'") recurrences, (f-f'”) LN metastasis. (a"'-f'”) phase contrast micrographs. Bars, $50 \mu \mathrm{m}$.

\section{Supplementary Material}

Supplementary Table S1. Detailed immunostaining results obtained for the Merkel carcinoma markers CK20 and chromogranin A and for AJ-associated proteins. C cytoskeletal pattern, D - perinuclear dots.

Supplementary Table S2. Survey of all desmosomal proteins detected in MCCs. P punctuate pattern typical of desmosomes, $L$ - linear immunofluorescence.

Supplementary Table S3. Immunoreactions observed with antibodies to TJ proteins. 


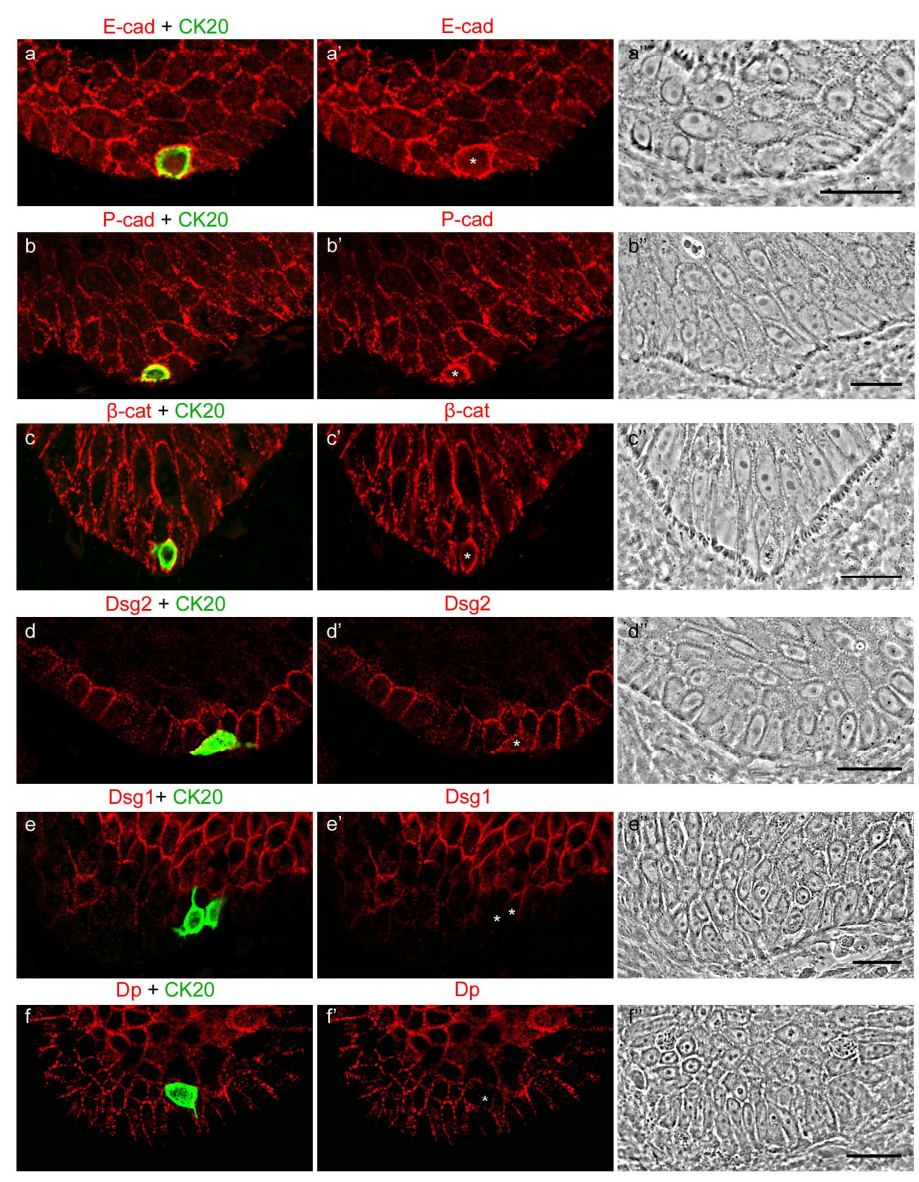

Figure 1

Figure 1

$209 \times 299 \mathrm{~mm}(300 \times 300 \mathrm{DPI})$ 


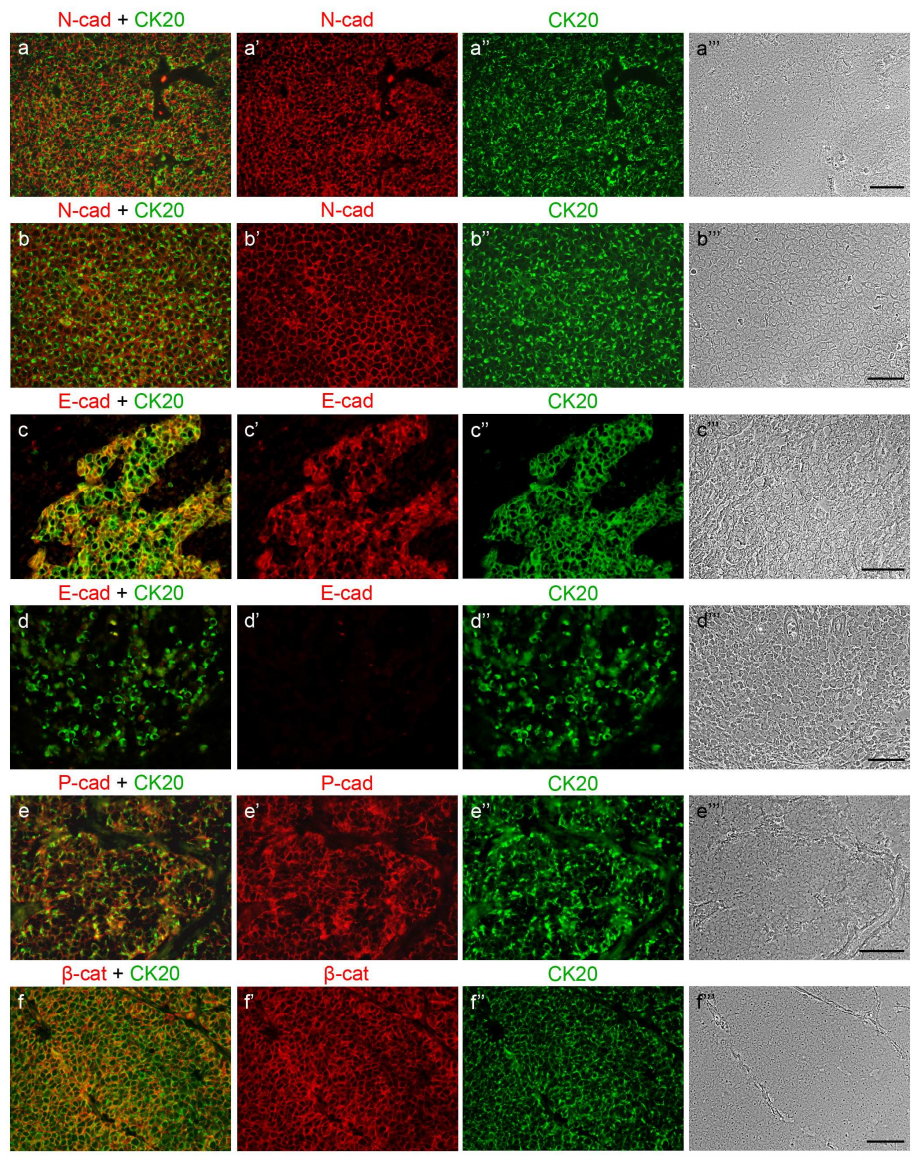

Figure 2

Figure 2

$209 \times 299 \mathrm{~mm}(300 \times 300$ DPI $)$ 


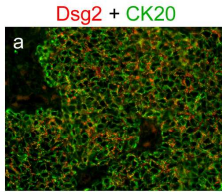

Dsg2

CK20
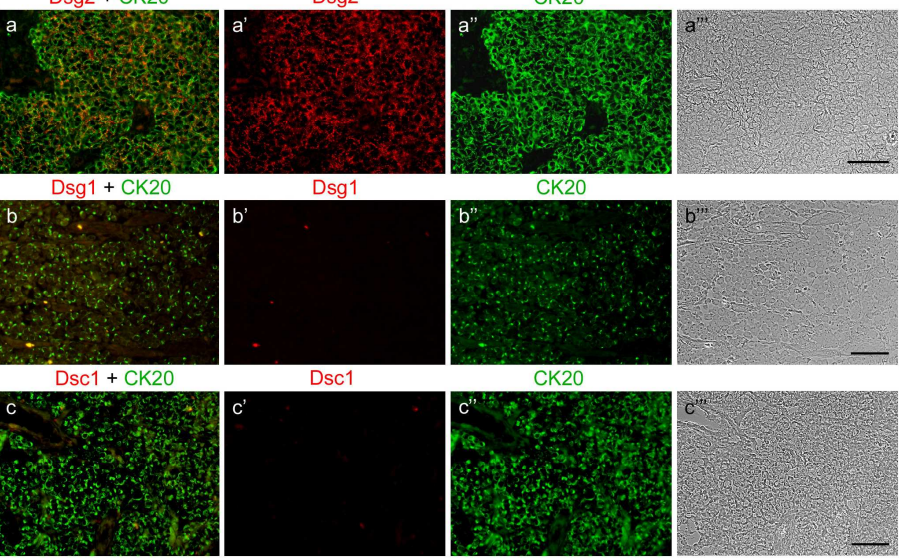

Dsg1

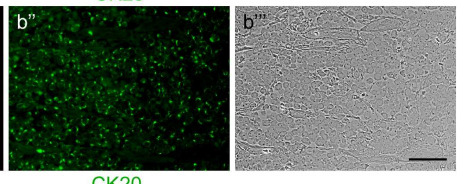

$\mathrm{Dp}+\mathrm{CK} 20$

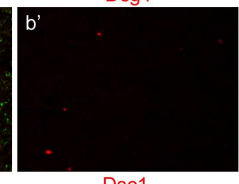

CK20
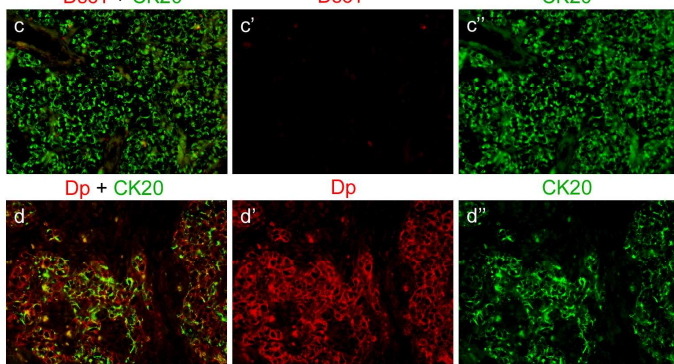

$\mathrm{Dp}+\mathrm{CK} 20$

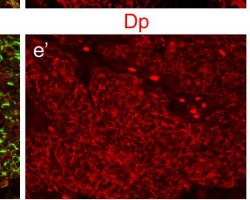

CK20
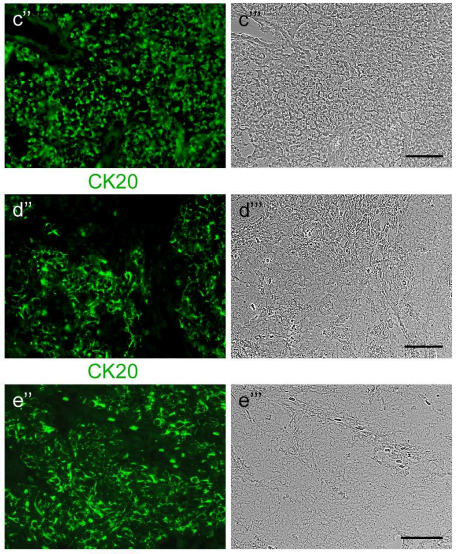

CK20
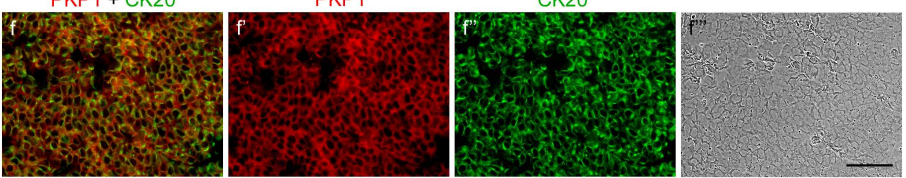

Figure 3

Figure 3

209x299mm (300 x 300 DPI) 


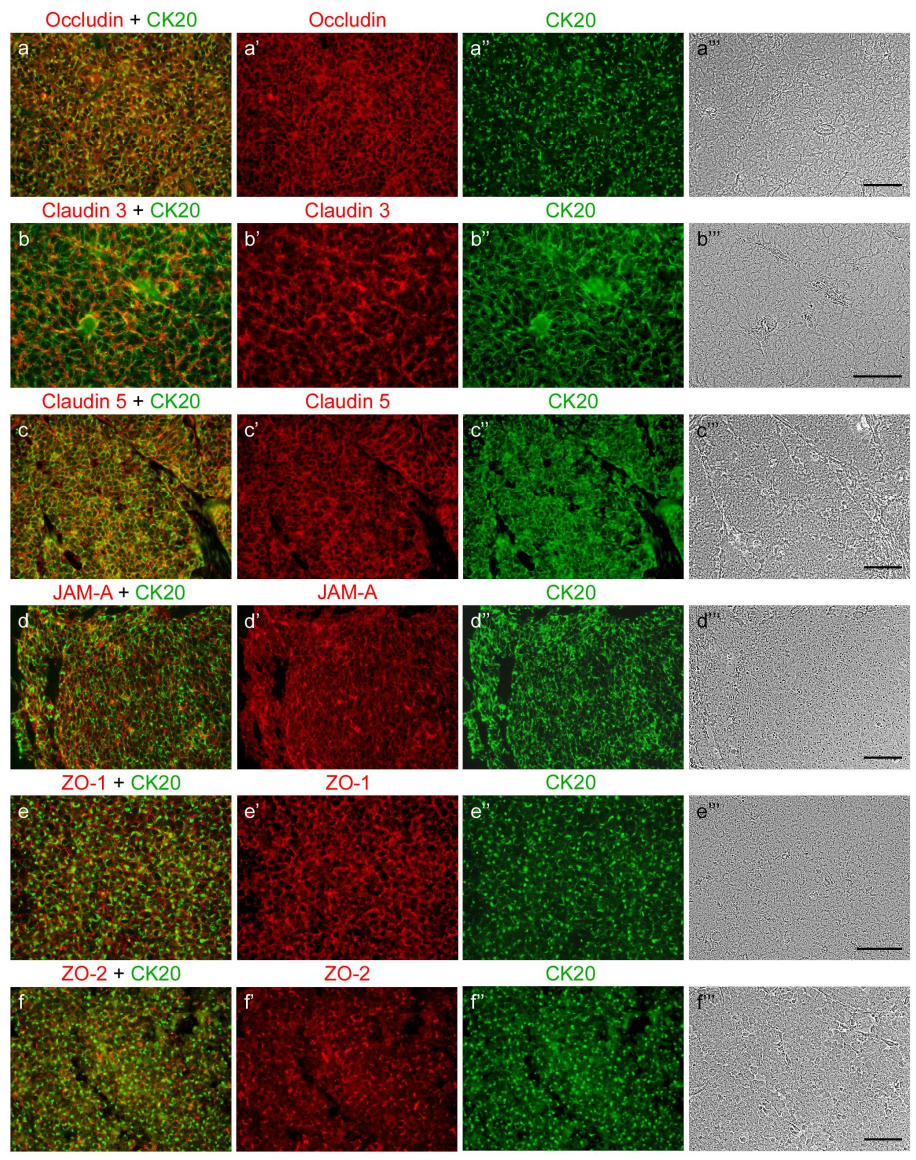

Figure 4

Figure 4

$209 \times 299 \mathrm{~mm}(300 \times 300$ DPI $)$ 


\begin{tabular}{|c|c|}
\hline \multicolumn{2}{|c|}{ AJ proteins } \\
\hline E-cad & + \\
\hline P-cad & + \\
\hline $\mathrm{N}$-cad & - \\
\hline$\alpha$-cat & + \\
\hline$\beta$-cat & + \\
\hline Protein $\mathrm{p} 120$ & + \\
\hline Plakoglobin (PG) & + \\
\hline \multicolumn{2}{|c|}{ Desmosomal proteins } \\
\hline Dsg 1 & - \\
\hline Dsg 2 & + \\
\hline Dsg 3 & n. d. \\
\hline Dsc 1 & - \\
\hline Dsc 2 & + \\
\hline Dsc 3 & - \\
\hline Desmoplakin (Dp) & + \\
\hline PKP 1 & + \\
\hline PKP 2 & - \\
\hline PKP 3 & + \\
\hline$P G$ & + \\
\hline
\end{tabular}

Table 1. AJ and desmosomal proteins detected at heterotypic contacts between Merkel cells and keratinocytes in normal glabrous epidermis. 


\begin{tabular}{|c|c|c|c|c|c|c|c|c|c|c|c|c|}
\hline Pat no. & $\begin{array}{c}\text { Age } \\
\text { (years) }\end{array}$ & Sex & Tumour & Localization & $\begin{array}{l}\text { MCPyV } \\
\text { status }\end{array}$ & $\begin{array}{l}\text { Initial } \\
\text { stage }\end{array}$ & $\begin{array}{l}\text { Recur- } \\
\text { rence }\end{array}$ & $\begin{array}{c}\text { Regio- } \\
\text { nal LN } \\
\text { met }\end{array}$ & Further met & $\begin{array}{c}\text { Max } \\
\text { stage }\end{array}$ & Result of last $F / U$ & $\begin{array}{c}\text { Length of } \\
F / U \\
\text { (months) }\end{array}$ \\
\hline 1 & 55 & $\mathrm{~m}$ & $\begin{array}{l}\text { 1a primary } \\
\text { 1b LN met }\end{array}$ & $\begin{array}{l}\text { 1a right knee } \\
1 \mathrm{~b} \text { right inguinal }\end{array}$ & $\begin{array}{l}\text { pos } \\
\text { pos }\end{array}$ & II & no & yes & no & II & disease-free & 39 \\
\hline 2 & 89 & $\mathrm{~m}$ & $\begin{array}{l}\text { 2a primary } \\
\text { 2b LN met } \\
\text { 2c LN met }\end{array}$ & $\begin{array}{l}2 a \text { left ear } \\
2 b \text { left cervix } \\
2 c \text { left cervix }\end{array}$ & $\begin{array}{l}\text { neg } \\
\text { neg } \\
\text { neg }\end{array}$ & II & yes & yes & no & II & $\begin{array}{l}\text { LN met right } \\
\text { clavicle }\end{array}$ & 9 \\
\hline 3 & 77 & $\mathrm{~m}$ & recurrence & gluteal & neg & III & yes & yes & $\begin{array}{l}\text { liver, retroperi- } \\
\text { toneal }\end{array}$ & III & deceased & 9 \\
\hline 4 & 87 & $f$ & primary & left ala of the nose & pos & 1 & n.d. & n.d. & n.d. & 1 & disease-free & 1 \\
\hline 5 & 69 & $\mathrm{~m}$ & $\begin{array}{l}\text { 5a primary } \\
\text { 5b LN met }\end{array}$ & $\begin{array}{l}5 a \text { left lower leg } \\
5 b \text { left inguinal }\end{array}$ & $\begin{array}{l}\text { pos } \\
\text { pos }\end{array}$ & II & no & yes & no & II & end of RT & 5 \\
\hline 6 & 69 & $f$ & primary & right elbow & pos & 1 & no & no & no & 1 & disease-free & 91 \\
\hline 7 & 60 & $f$ & primary & left elbow & pos & 1 & no & no & no & 1 & disease-free & 76 \\
\hline 8 & 71 & $f$ & primary & left forearm & pos & 1 & n.d. & n.d & n.d. & n.d. & deceased & 13 \\
\hline 9 & 75 & $\mathrm{~m}$ & $\begin{array}{l}\text { 9a LN met } \\
9 \mathrm{~b} \text { met }\end{array}$ & $\begin{array}{l}\text { 9a right axilla } \\
\text { 9b right thoracic wall }\end{array}$ & $\begin{array}{l}\text { pos } \\
\text { pos }\end{array}$ & 1 & no & yes & $\begin{array}{l}\text { right thoracic } \\
\text { wall }\end{array}$ & II & disease-free & 32 \\
\hline 10 & 61 & $f$ & $\begin{array}{l}\text { 10a primary } \\
\text { 10b recurrence } \\
\text { 10c met }\end{array}$ & $\begin{array}{l}\text { 10a left upper eyelid } \\
\text { 10b left upper eyelid } \\
\text { 10c parotid gland }\end{array}$ & $\begin{array}{l}\text { pos } \\
\text { pos } \\
\text { pos }\end{array}$ & 1 & yes & yes & $\begin{array}{l}\text { parotid gland, } \\
\text { stomach }\end{array}$ & III & gastric met & 12 \\
\hline 11 & 76 & $\mathrm{~m}$ & $\begin{array}{l}\text { 11a primary } \\
\text { 11b recurrence } \\
\text { 11c LN met }\end{array}$ & $\begin{array}{l}\text { 11a left thoracic wall } \\
11 b \text { left thoracic wall } \\
\text { 11c left axilla }\end{array}$ & $\begin{array}{l}\text { pos } \\
\text { pos } \\
\text { pos }\end{array}$ & 1 & yes & yes & n.d. & II & LN met left axilla & 17 \\
\hline 12 & 67 & $f$ & $\begin{array}{l}\text { 12a primary } \\
\text { 12b LN met }\end{array}$ & $\begin{array}{l}\text { 12a left lower leg } \\
12 b \text { left inguinal }\end{array}$ & $\begin{array}{l}\text { pos } \\
\text { pos }\end{array}$ & II & no & yes & no & II & end of RT & 4 \\
\hline 13 & 80 & $f$ & primary & right eye brow & pos & 1 & n.d. & n.d. & n.d. & 1 & disease-free & 1 \\
\hline 14 & 76 & $\mathrm{~m}$ & $\begin{array}{l}\text { 14a primary } \\
\text { 14b LN met }\end{array}$ & $\begin{array}{l}\text { 14a right gluteal } \\
14 \mathrm{~b} \text { right inguinal }\end{array}$ & $\begin{array}{l}\text { pos } \\
\text { pos }\end{array}$ & II & n.d. & yes & right iliac spine & II & disease-free & 33 \\
\hline 15 & 82 & $f$ & $\begin{array}{l}\text { 15a primary } \\
\text { 15b LN met }\end{array}$ & $\begin{array}{l}\text { 15a left gluteal } \\
15 b \text { left gluteal }\end{array}$ & $\begin{array}{l}\text { pos } \\
\text { pos }\end{array}$ & II & yes & yes & retroperitoneal & III & deceased & 6 \\
\hline
\end{tabular}




\begin{tabular}{|c|c|c|c|c|c|c|c|c|c|c|c|c|}
\hline 16 & 69 & $\mathrm{~m}$ & primary & right forearm & pos & 1 & no & no & no & I & disease-free & 97 \\
\hline 17 & 77 & $f$ & LN met & right inguinal & pos & II & n.d. & yes & n.d. & II & LN met surgery & 0 \\
\hline 18 & 69 & $\mathrm{~m}$ & $\begin{array}{l}\text { 18a primary } \\
\text { 18b recurrence } \\
18 c \text { LN met }\end{array}$ & $\begin{array}{l}18 \mathrm{a} \text { right thigh } \\
18 \mathrm{~b} \text { right thigh } \\
18 \mathrm{c} \text { right inguinal }\end{array}$ & $\begin{array}{l}\text { pos } \\
\text { pos } \\
\text { pos }\end{array}$ & II & yes & yes & no & II & under RT & 5 \\
\hline 19 & 74 & $\mathrm{~m}$ & primary & n.d. & pos & n.d. & n.d. & n.d. & n.d. & n.d. & primary surgery & 0 \\
\hline 20 & 72 & $f$ & $\begin{array}{l}\text { 20a primary } \\
20 \mathrm{~b} \text { recurrence } \\
20 \mathrm{c} \text { recurrence } \\
\text { 20d LN met }\end{array}$ & $\begin{array}{l}20 \mathrm{a} \text { right thigh } \\
20 \mathrm{~b} \text { right thigh } \\
20 \mathrm{c} \text { right thigh } \\
20 \mathrm{~d} \text { right inguinal }\end{array}$ & $\begin{array}{l}\text { pos } \\
\text { pos } \\
\text { pos } \\
\text { pos }\end{array}$ & 1 & yes & yes & $\begin{array}{l}\text { retroperitoneal, } \\
\text { paraaortic }\end{array}$ & III & disease-free & 120 \\
\hline 21 & 92 & $\mathrm{~m}$ & $\begin{array}{l}\text { 21a recurrence } \\
21 b \mathrm{LN} \text { met }\end{array}$ & $\begin{array}{l}\text { 21a left cheek } \\
21 \mathrm{~b} \text { left cervix }\end{array}$ & $\begin{array}{l}\text { pos } \\
\text { pos }\end{array}$ & n.d. & yes & yes & liver & III & $\begin{array}{l}\text { cervical LN met, } \\
\text { liver met }\end{array}$ & 2 \\
\hline 22 & 63 & $f$ & primary & right elbow & pos & II & n.d. & yes & n.d. & II & primary surgery & 0 \\
\hline 23 & 67 & $f$ & primary & left gluteal & n.d. & n.d. & n.d. & n.d. & n.d. & n.d. & primary surgery & 0 \\
\hline 24 & 53 & $\mathrm{~m}$ & primary & left thigh & neg & II & no & yes & no & II & disease-free & 54 \\
\hline 25 & 76 & $f$ & primary & right forearm & pos & 1 & yes & no & no & 1 & $\begin{array}{l}\text { surgery of } \\
\text { recurrence }\end{array}$ & 4 \\
\hline 26 & 82 & $f$ & primary & right upper eyelid & pos & 1 & n.d. & n.d. & n.d. & 1 & primary surgery & 0 \\
\hline 27 & 80 & $f$ & recurrence & left lower eyelid & pos & 1 & yes & no & no & 1 & end of RT & 17 \\
\hline 28 & 75 & $\mathrm{~m}$ & $\begin{array}{l}\text { 28a primary } \\
\text { 28b LN met }\end{array}$ & $\begin{array}{l}28 \text { a right cheek } \\
28 \mathrm{~b} \text { right cervix }\end{array}$ & $\begin{array}{l}\text { neg } \\
\text { neg }\end{array}$ & II & no & yes & skeletal, liver & III & liver and spinal met & 5 \\
\hline 29 & 75 & $\mathrm{~m}$ & primary & right temporal & n.d. & 1 & no & no & no & 1 & disease-free & 76 \\
\hline 30 & 75 & $f$ & $\begin{array}{l}\text { 30a recurrence } \\
\text { 30b LN met }\end{array}$ & $\begin{array}{l}\text { 30a right lower leg } \\
\text { 30b right inguinal }\end{array}$ & $\begin{array}{l}\text { pos } \\
\text { pos }\end{array}$ & 1 & yes & yes & no & II & disease-free & 11 \\
\hline 31 & 74 & $f$ & primary & occiput & neg & n.d. & n.d. & n.d. & n.d. & n.d. & primary surgery & 0 \\
\hline 32 & 90 & $f$ & primary & right lower eyelid & pos & 1 & n.d. & n.d. & n.d. & 1 & primary surgery & 0 \\
\hline
\end{tabular}

Table 2. Clinical data and MCV status of patients with MCC. Pat - patient, LN met - lymph node metastasis, mets metastases, F/U - follow up, RT - radiation therapy, $m$ - male, $f$ - female, n.d. - not determined, max - maximal, pos positive, neg - negative. 


\begin{tabular}{|l|c|c|c|c|c|c|c|c|}
\hline & N-cad & E-cad & P-cad & VE-cad & $\boldsymbol{\alpha}$-cat & $\boldsymbol{\beta}$-cat & p120 & PG \\
\hline All MCCs, $\mathbf{n}=\mathbf{5 2}$ & $90.4 \%$ & $66.7 \%$ & $65.4 \%$ & $0 \%$ & $92 \%$ & $98 \%$ & $85.7 \%$ & $53.1 \%$ \\
\hline Primary tumours, $\mathbf{n = 2 6}$ & $92.3 \%$ & $64 \%$ & $76.9 \%$ & $0 \%$ & $100 \%$ & $100 \%$ & $84 \%$ & $56.5 \%$ \\
\hline Recurrences, $\mathbf{n = 9}$ & $77.8 \%$ & $66.7 \%$ & $77.8 \%$ & $0 \%$ & $75 \%$ & $100 \%$ & $100 \%$ & $55.6 \%$ \\
\hline LN metastases, $\mathbf{n = 1 5}$ & $93.3 \%$ & $66.7 \%$ & $33.3 \%$ & $0 \%$ & $85.7 \%$ & $93.3 \%$ & $86.7 \%$ & $46.7 \%$ \\
\hline Other metastases, $\mathbf{n = 2}$ & $2 / 2$ & $2 / 2$ & $2 / 2$ & $0 / 0$ & $2 / 2$ & $2 / 2$ & $1 / 2$ & $1 / 2$ \\
\hline
\end{tabular}

Table 3. Percentage of MCCs containing classical cads and AJ-associated plaque proteins. PG - plakoglobin. 


\begin{tabular}{|c|c|c|c|c|c|c|}
\hline & \multicolumn{2}{|c|}{ All primary tumours, $\mathbf{n}=\mathbf{2 6}$} & \multicolumn{2}{c|}{ P-cad-pos primaries, $\mathbf{n = 2 0}$} & \multicolumn{2}{c|}{ P-cad-neg primaries, $\mathbf{n}=\mathbf{6}$} \\
\hline Stage & initial & maximal & initial & maximal & initial & maximal \\
\hline I & $50 \%$ & $35 \%$ & $65 \%$ & $45 \%$ & $0 \%$ & $0 \%$ \\
\hline II & $39 \%$ & $35 \%$ & $25 \%$ & $30 \%$ & $83 \%$ & $50 \%$ \\
\hline III & $0 \%$ & $15 \%$ & $0 \%$ & $10 \%$ & $0 \%$ & $33 \%$ \\
\hline n. d. & $11 \%$ & $15 \%$ & $10 \%$ & $15 \%$ & $17 \%$ & $17 \%$ \\
\hline
\end{tabular}

Table 4. Correlation between the presence of P-cad in primary MCCs and the initial and maximal clinical stage, the latter determined at the end of the follow up. 


\begin{tabular}{|c|c|c|c|c|c|c|c|c|c|c|}
\hline & Dsg1 & Dsg2 & Dsc1 & Dsc2 & Dsc3 & Dp & PKP1 & PKP2 & PKP3 & PG \\
\hline All MCCs, $n=52$ & $0 \%$ & $61.5 \%$ & $4.3 \%$ & $6.1 \%$ & $2 \%$ & $36.7 \%$ & $60.8 \%$ & $44.9 \%$ & $31.1 \%$ & $53.1 \%$ \\
\hline Primary tumours, $n=26$ & $0 \%$ & $61.5 \%$ & $8.7 \%$ & $13 \%$ & $4 \%$ & $20 \%$ & $65.4 \%$ & $47.8 \%$ & $40.9 \%$ & $56.5 \%$ \\
\hline Recurrences, $n=9$ & $0 \%$ & $55.6 \%$ & $0 \%$ & $0 \%$ & $0 \%$ & $44.4 \%$ & $22.2 \%$ & $55.5 \%$ & $44.4 \%$ & $55.6 \%$ \\
\hline Other metastases, $n=2$ & $0 / 2$ & $2 / 2$ & $0 / 2$ & $0 / 2$ & $0 / 2$ & $0 / 2$ & $2 / 2$ & $0 / 2$ & $0 / 2$ & $1 / 2$ \\
\hline
\end{tabular}

Table 5. Proportion of primary MCCs, recurrences and LN metastases containing desmosomal cads and plaque proteins. 


\begin{tabular}{|c|c|c|c|c|c|c|c|c|c|}
\hline & Claudin 1 & Claudin 2 & Claudin 3 & Claudin 4 & Claudin 5 & Occludin & JAM-A & $\mathrm{ZO}-1$ & ZO-2 \\
\hline All MCCs, $n=52$ & $20.4 \%$ & $0 \%$ & $63.3 \%$ & $12.2 \%$ & $86 \%$ & $58.8 \%$ & $60.4 \%$ & $58 \%$ & $64 \%$ \\
\hline Primary tumours, $n=26$ & $25 \%$ & $0 \%$ & $64 \%$ & $12.5 \%$ & $96 \%$ & $56 \%$ & $52.2 \%$ & $56 \%$ & $76 \%$ \\
\hline Recurrences, $\mathrm{n}=\mathbf{9}$ & $11.1 \%$ & $0 \%$ & $33.3 \%$ & $0 \%$ & $66.7 \%$ & $55.6 \%$ & $77.8 \%$ & $55.6 \%$ & $37.5 \%$ \\
\hline LN metastases, $n=15$ & $21.4 \%$ & $0 \%$ & $76.9 \%$ & $21.4 \%$ & $78.6 \%$ & $66.7 \%$ & $57.1 \%$ & $57.1 \%$ & $60 \%$ \\
\hline Other metastases, $n=2$ & $0 / 2$ & $0 / 2$ & $2 / 2$ & $0 / 2$ & $2 / 2$ & $1 / 2$ & $2 / 2$ & $2 / 2$ & $1 / 2$ \\
\hline
\end{tabular}

Table 6. Frequency of TJ proteins in MCCs. 
Supplementary Table S1. Detailed immunostaining results obtained for the Merkel carcinoma markers CK20 and chromogranin A and for AJ-associated proteins.

\begin{tabular}{|c|c|c|c|c|c|c|c|c|c|c|c|c|c|}
\hline $\begin{array}{l}\text { Pat } \\
\text { no. }\end{array}$ & Tumour & Localization & $\begin{array}{c}\text { Histological } \\
\text { subtype }\end{array}$ & CK20 & $\begin{array}{l}\text { Chro- } \\
\text { mo A }\end{array}$ & $\mathrm{N}$-cad & E-cad & P-cad & $\begin{array}{l}\text { VE- } \\
\text { cad }\end{array}$ & $\alpha$-cat & $\beta$-cat & p120 & PG \\
\hline 1 & $\begin{array}{l}\text { 1a primary } \\
\text { 1b LN met }\end{array}$ & $\begin{array}{l}\text { 1a right knee } \\
\text { 1b right inguinal }\end{array}$ & $\begin{array}{l}\text { trabecular } \\
\text { trabecular }\end{array}$ & $\begin{array}{l}+D \\
+D\end{array}$ & - & $\begin{array}{l}+ \\
+\end{array}$ & - & - & - & $\begin{array}{l}+ \\
+\end{array}$ & $\begin{array}{l}+ \\
+\end{array}$ & $\begin{array}{l}- \\
+\end{array}$ & $\begin{array}{l}- \\
-\end{array}$ \\
\hline 2 & $\begin{array}{l}\text { 2a primary } \\
\text { 2b LN met } \\
\text { 2c LN met }\end{array}$ & $\begin{array}{l}\text { 2a left ear } \\
2 b \text { left cervix } \\
2 c \text { left cervix }\end{array}$ & $\begin{array}{l}\text { intermediate } \\
\text { intermediate } \\
\text { intermediate }\end{array}$ & $\begin{array}{l}+C \\
+C \\
+C\end{array}$ & $\begin{array}{l}+ \\
+ \\
+\end{array}$ & $\begin{array}{l}+ \\
+ \\
-\end{array}$ & $\begin{array}{l}+ \\
+ \\
+\end{array}$ & $\begin{array}{l}- \\
- \\
-\end{array}$ & $\begin{array}{l}- \\
- \\
-\end{array}$ & $\begin{array}{l}+ \\
+ \\
-\end{array}$ & $\begin{array}{l}+ \\
+ \\
+\end{array}$ & $\begin{array}{l}+ \\
- \\
+\end{array}$ & $\begin{array}{l}- \\
+ \\
+\end{array}$ \\
\hline 3 & recurrence & gluteal & small cell & $+C$ & + & + & + & + & - & - & + & n.d. & - \\
\hline 4 & primary & left ala of the nose & intermediate & $+\mathrm{C}$ & + & + & + & + & - & + & + & + & - \\
\hline 5 & $\begin{array}{l}\text { 5a primary } \\
5 b \text { LN met }\end{array}$ & $\begin{array}{l}5 a \text { left lower leg } \\
5 b \text { left inguinal }\end{array}$ & $\begin{array}{c}\text { trabecular } \\
\text { intermediate }\end{array}$ & $+C$ & + & $\begin{array}{l}+ \\
+ \\
\end{array}$ & + & + & $\begin{array}{l}- \\
-\end{array}$ & + & + & $\begin{array}{l}+ \\
+\end{array}$ & + \\
\hline 6 & primary & right elbow & small cell & $+\mathrm{C}$ & + & + & + & + & - & + & + & + & + \\
\hline 7 & primary & left elbow & trabecular & $+D$ & - & + & - & + & - & + & + & + & - \\
\hline 8 & primary & left forearm & intermediate & - & - & - & + & + & - & + & + & + & - \\
\hline 9 & $\begin{array}{l}\text { 9a LN met } \\
9 \mathrm{~b} \text { met }\end{array}$ & $\begin{array}{l}\text { 9a right axilla } \\
\text { 9b right thoracic wall }\end{array}$ & $\begin{array}{l}\text { small cell } \\
\text { small cell }\end{array}$ & $\begin{array}{l}+C \\
+C \\
\end{array}$ & - & $\begin{array}{l}+ \\
+ \\
\end{array}$ & $\begin{array}{l}+ \\
+ \\
\end{array}$ & $\begin{array}{l}- \\
+ \\
\end{array}$ & $\begin{array}{l}- \\
-\end{array}$ & $\begin{array}{l}+ \\
+\end{array}$ & $\begin{array}{l}+ \\
+\end{array}$ & $\begin{array}{l}+ \\
+\end{array}$ & - \\
\hline 10 & $\begin{array}{l}\text { 10a primary } \\
\text { 10b recurrence } \\
10 \mathrm{c} \text { met }\end{array}$ & $\begin{array}{l}\text { 10a left upper eyelid } \\
\text { 10b left upper eyelid } \\
\text { 10c parotid gland }\end{array}$ & $\begin{array}{c}\text { trabecular } \\
\text { intermediate } \\
\text { trabecular }\end{array}$ & $\begin{array}{l}+D \\
+D \\
+D\end{array}$ & $\begin{array}{l}+ \\
+ \\
+\end{array}$ & $\begin{array}{l}+ \\
+ \\
+\end{array}$ & $\begin{array}{l}+ \\
+ \\
+\end{array}$ & $\begin{array}{l}+ \\
+ \\
+\end{array}$ & $\begin{array}{l}- \\
- \\
-\end{array}$ & $\begin{array}{l}+ \\
+ \\
+\end{array}$ & $\begin{array}{l}+ \\
+ \\
+\end{array}$ & $\begin{array}{c}+ \\
\text { n.d. } \\
-\end{array}$ & $\begin{array}{l}+ \\
+ \\
+\end{array}$ \\
\hline 11 & $\begin{array}{l}\text { 11a primary } \\
11 \mathrm{~b} \text { recurrence } \\
11 \mathrm{c} L N \text { met }\end{array}$ & $\begin{array}{l}\text { 11a left thoracic wall } \\
11 \mathrm{~b} \text { left thoracic wall } \\
11 \mathrm{c} \text { left axilla }\end{array}$ & $\begin{array}{l}\text { intermediate } \\
\text { trabecular } \\
\text { intermediate }\end{array}$ & $\begin{array}{l}+C \\
+C \\
+C\end{array}$ & $\begin{array}{l}+ \\
+ \\
+\end{array}$ & $\begin{array}{l}+ \\
+ \\
+\end{array}$ & $\begin{array}{l}+ \\
+ \\
+\end{array}$ & $\begin{array}{l}+ \\
+ \\
+\end{array}$ & $\begin{array}{l}- \\
- \\
-\end{array}$ & $\begin{array}{l}+ \\
+ \\
+\end{array}$ & $\begin{array}{l}+ \\
+ \\
+\end{array}$ & $\begin{array}{l}+ \\
+ \\
-\end{array}$ & $\begin{array}{l}+ \\
+ \\
-\end{array}$ \\
\hline 12 & $\begin{array}{l}\text { 12a primary } \\
12 \mathrm{~b} L N \text { met }\end{array}$ & $\begin{array}{l}12 a \text { left lower leg } \\
12 b \text { left inguinal }\end{array}$ & $\begin{array}{l}\text { small cell } \\
\text { small cell }\end{array}$ & $\begin{array}{l}+D \\
+C \\
\end{array}$ & $\begin{array}{l}+ \\
+ \\
\end{array}$ & $\begin{array}{l}+ \\
+ \\
\end{array}$ & $\begin{array}{c}\text { n.d. } \\
-\end{array}$ & + & $\begin{array}{c}\text { n.d. } \\
-\end{array}$ & $\begin{array}{l}+ \\
+ \\
\end{array}$ & $\begin{array}{l}+ \\
+ \\
\end{array}$ & $\begin{array}{l}- \\
+ \\
\end{array}$ & $\begin{array}{l}- \\
-\end{array}$ \\
\hline 13 & primary & right eye brow & small cell & $+C(D)$ & + & + & + & + & - & + & + & + & + \\
\hline 14 & $\begin{array}{l}\text { 14a primary } \\
\text { 14b LN met }\end{array}$ & $\begin{array}{l}\text { 14a right gluteal } \\
\text { 14b right inguinal }\end{array}$ & $\begin{array}{l}\text { small cell } \\
\text { small cell }\end{array}$ & $\begin{array}{l}+\mathrm{C} \\
+\mathrm{C}\end{array}$ & + & $\begin{array}{l}+ \\
+\end{array}$ & $\begin{array}{l}+ \\
+\end{array}$ & $\begin{array}{l}+ \\
+\end{array}$ & $\begin{array}{l}- \\
-\end{array}$ & $\begin{array}{l}+ \\
+\end{array}$ & $\begin{array}{l}+ \\
+\end{array}$ & $\begin{array}{l}+ \\
+\end{array}$ & $\begin{array}{l}+ \\
+\end{array}$ \\
\hline
\end{tabular}




\begin{tabular}{|c|c|c|c|c|c|c|c|c|c|c|c|c|c|}
\hline 15 & $\begin{array}{l}\text { 15a primary } \\
15 b \text { LN met }\end{array}$ & $\begin{array}{l}15 \mathrm{a} \text { left gluteal } \\
15 \mathrm{~b} \text { left gluteal }\end{array}$ & $\begin{array}{l}\text { intermediate } \\
\text { intermediate }\end{array}$ & $\begin{array}{l}+D \\
+D\end{array}$ & $\begin{array}{l}\text { n.d. } \\
\text { n.d. }\end{array}$ & $\begin{array}{l}+ \\
+\end{array}$ & $\begin{array}{l}- \\
-\end{array}$ & - & $\begin{array}{c}- \\
\text { n.d. }\end{array}$ & $\begin{array}{c}+ \\
\text { n.d. }\end{array}$ & $\begin{array}{l}+ \\
+\end{array}$ & $\begin{array}{l}+ \\
+\end{array}$ & + \\
\hline 16 & primary & right forearm & trabecular & $+D(C)$ & + & + & + & + & - & + & + & - & + \\
\hline 17 & LN met & right inguinal & intermediate & $+C$ & + & + & + & + & - & + & + & + & + \\
\hline 18 & $\begin{array}{l}\text { 18a primary } \\
\text { 18b recurrence } \\
18 c \text { LN met }\end{array}$ & $\begin{array}{l}18 \mathrm{a} \text { right thigh } \\
18 \mathrm{~b} \text { right thigh } \\
18 \mathrm{c} \text { right inguinal }\end{array}$ & $\begin{array}{l}\text { small cell } \\
\text { small cell } \\
\text { small cell }\end{array}$ & $\begin{array}{l}+D \\
+D \\
+D\end{array}$ & $\begin{array}{l}+ \\
- \\
+\end{array}$ & $\begin{array}{l}+ \\
+ \\
+\end{array}$ & $\begin{array}{l}- \\
- \\
-\end{array}$ & $\begin{array}{l}- \\
- \\
-\end{array}$ & $\begin{array}{l}- \\
- \\
-\end{array}$ & $\begin{array}{l}+ \\
+ \\
+\end{array}$ & $\begin{array}{l}+ \\
+ \\
+\end{array}$ & $\begin{array}{l}+ \\
+ \\
+\end{array}$ & $\begin{array}{c}\text { n.d. } \\
- \\
-\end{array}$ \\
\hline 19 & primary & $8+$ & intermediate & $+\mathrm{C}$ & + & + & + & + & - & + & + & + & + \\
\hline 20 & $\begin{array}{l}\text { 20a primary } \\
20 \mathrm{~b} \text { recurrence } \\
20 \mathrm{c} \text { recurrence } \\
20 \mathrm{~d} \text { LN met }\end{array}$ & $\begin{array}{l}20 \mathrm{a} \text { right thigh } \\
20 \mathrm{~b} \text { right thigh } \\
20 \mathrm{c} \text { right thigh } \\
20 \mathrm{~d} \text { right inguinal }\end{array}$ & $\begin{array}{l}\text { small cell } \\
\text { small cell } \\
\text { small cell } \\
\text { small cell }\end{array}$ & $\begin{array}{l}+D(C) \\
+D \\
+D \\
+D\end{array}$ & $\begin{array}{l}+ \\
+ \\
+ \\
+\end{array}$ & $\begin{array}{l}+ \\
- \\
+ \\
+\end{array}$ & $\begin{array}{l}+ \\
- \\
- \\
+\end{array}$ & $\begin{array}{l}+ \\
- \\
+ \\
+\end{array}$ & $\begin{array}{l}- \\
- \\
- \\
-\end{array}$ & $\begin{array}{l}+ \\
- \\
+ \\
+\end{array}$ & $\begin{array}{l}+ \\
+ \\
+ \\
+\end{array}$ & $\begin{array}{l}- \\
+ \\
+ \\
+\end{array}$ & $\begin{array}{l}- \\
- \\
+ \\
+\end{array}$ \\
\hline 21 & $\begin{array}{l}\text { 21a recurrence } \\
\text { 21b LN met }\end{array}$ & $\begin{array}{l}\text { 21a left cheek } \\
21 b \text { left cervix }\end{array}$ & $\begin{array}{c}\text { intermediate } \\
\text { trabecular }\end{array}$ & $\begin{array}{l}+C \\
+C\end{array}$ & $\begin{array}{l}+ \\
+\end{array}$ & $\begin{array}{l}+ \\
+\end{array}$ & $\begin{array}{l}+ \\
+\end{array}$ & $\begin{array}{l}+ \\
+\end{array}$ & - & $\begin{array}{l}+ \\
+\end{array}$ & $\begin{array}{l}+ \\
+\end{array}$ & $\begin{array}{l}+ \\
+\end{array}$ & $\begin{array}{l}+ \\
+\end{array}$ \\
\hline 22 & primary & right elbow & trabecular & $+C$ & + & + & + & + & - & + & + & + & + \\
\hline 23 & primary & left gluteal & small cell & $+C$ & - & + & - & + & - & + & + & + & + \\
\hline 24 & primary & left thigh & small cell & $+C$ & + & + & - & + & - & + & + & + & + \\
\hline 25 & primary & right forearm & intermediate & $+\mathrm{C}$ & + & + & - & + & - & + & + & + & - \\
\hline 26 & primary & right upper eyelid & intermediate & $+\mathrm{C}$ & + & + & + & + & - & + & + & + & n.d. \\
\hline 27 & recurrence & left lower eyelid & trabecular & $+D$ & + & + & + & + & - & + & + & + & - \\
\hline 28 & $\begin{array}{l}\text { 28a primary } \\
\text { 28b LN met }\end{array}$ & $\begin{array}{l}28 a \text { right cheek } \\
28 b \text { right cervix }\end{array}$ & $\begin{array}{l}\text { intermediate } \\
\text { intermediate }\end{array}$ & $+\mathrm{C}$ & $\begin{array}{l}+ \\
+\end{array}$ & $\begin{array}{l}+ \\
+ \\
\end{array}$ & $\begin{array}{l}+ \\
+\end{array}$ & - & - & $\begin{array}{l}+ \\
+\end{array}$ & $\begin{array}{l}+ \\
+\end{array}$ & $\begin{array}{l}+ \\
+\end{array}$ & + \\
\hline 29 & primary & right temporal & intermediate & $+C$ & n.d. & - & - & + & n.d. & + & n.d. & n.d. & n.d. \\
\hline 30 & $\begin{array}{l}\text { 30a recurrence } \\
\text { 30b LN met }\end{array}$ & $\begin{array}{l}\text { 30a right lower leg } \\
30 \mathrm{~b} \text { right inguinal }\end{array}$ & $\begin{array}{l}\text { intermediate } \\
\text { intermediate }\end{array}$ & $\begin{array}{l}+\mathrm{C} \\
+\mathrm{C}\end{array}$ & - & $\begin{array}{l}- \\
+\end{array}$ & $\begin{array}{l}+ \\
+\end{array}$ & $\begin{array}{l}+ \\
-\end{array}$ & - & $\begin{array}{c}\text { n.d. } \\
+\end{array}$ & $\begin{array}{l}+ \\
+\end{array}$ & $\begin{array}{l}+ \\
+\end{array}$ & $\begin{array}{l}+ \\
+\end{array}$ \\
\hline 31 & primary & occiput & trabecular & - & + & + & + & - & - & + & + & + & - \\
\hline 32 & primary & right lower eyelid & small cell & $+\mathrm{C}$ & + & + & - & + & - & + & + & + & - \\
\hline
\end{tabular}

\section{C - cytoskeletal pattern, D - perinuclear dots.}

Published on behalf of the British Division of the International Academy of Pathology 
Supplementary Table S2. Survey of all desmosomal proteins detected in MCCs.

\begin{tabular}{|c|c|c|c|c|c|c|c|c|c|c|c|c|c|}
\hline $\begin{array}{l}\text { Pat } \\
\text { no. }\end{array}$ & Tumour & Localization & $\begin{array}{l}\text { Histological } \\
\text { subtype }\end{array}$ & Dsg1 & Dsg2 & Dsc1 & Dsc2 & Dsc3 & $D p$ & PKP1 & PKP2 & PKP3 & $P G$ \\
\hline 1 & $\begin{array}{l}\text { 1a primary } \\
\text { 1b LN met }\end{array}$ & $\begin{array}{l}\text { 1a right knee } \\
1 \mathrm{~b} \text { right inguinal }\end{array}$ & $\begin{array}{l}\text { trabecular } \\
\text { trabecular }\end{array}$ & $\begin{array}{l}- \\
-\end{array}$ & $\begin{array}{l}- \\
-\end{array}$ & $\begin{array}{l}- \\
-\end{array}$ & $\begin{array}{l}- \\
-\end{array}$ & $\begin{array}{l}- \\
-\end{array}$ & $\begin{array}{l}- \\
-\end{array}$ & $\begin{array}{l}+ \\
+\end{array}$ & $\begin{array}{l}+ \\
+\end{array}$ & $\begin{array}{l}- \\
-\end{array}$ & $\begin{array}{l}- \\
-\end{array}$ \\
\hline 2 & $\begin{array}{l}\text { 2a primary } \\
\text { 2b LN met } \\
\text { 2c LN met }\end{array}$ & $\begin{array}{l}\text { 2a left ear } \\
2 b \text { left cervix } \\
2 c \text { left cervix }\end{array}$ & $\begin{array}{l}\text { intermediate } \\
\text { intermediate } \\
\text { intermediate }\end{array}$ & $\begin{array}{l}- \\
- \\
-\end{array}$ & $\begin{array}{l}+P \\
+P \\
+P\end{array}$ & $\begin{array}{l}- \\
- \\
-\end{array}$ & $\begin{array}{l}- \\
- \\
-\end{array}$ & $\begin{array}{l}- \\
- \\
-\end{array}$ & $\begin{array}{l}+ \\
+ \\
+\end{array}$ & $\begin{array}{l}+ \\
+ \\
+\end{array}$ & $\begin{array}{l}+ \\
+ \\
-\end{array}$ & $\begin{array}{c}\text { - } \\
\text { n.d. } \\
-\end{array}$ & $\begin{array}{l}- \\
+ \\
+\end{array}$ \\
\hline 3 & recurrence & gluteal & small cell & - & $+P$ & - & - & - & + & - & + & - & - \\
\hline 4 & primary & left ala of the nose & intermediate & - & $+L$ & - & - & - & - & + & - & - & - \\
\hline 5 & $\begin{array}{l}\text { 5a primary } \\
5 b \text { LN met }\end{array}$ & $\begin{array}{l}5 a \text { left lower leg } \\
5 b \text { left inguinal }\end{array}$ & $\begin{array}{l}\text { trabecular } \\
\text { intermediate }\end{array}$ & - & $+\mathrm{L}$ & - & + & - & - & $\begin{array}{l}+ \\
+\end{array}$ & $\begin{array}{l}+ \\
+\end{array}$ & $\begin{array}{c}+ \\
\text { n.d }\end{array}$ & + \\
\hline 6 & primary & right elbow & small cell & - & $+P$ & + & + & - & + & + & n.d. & + & + \\
\hline 7 & primary & left elbow & trabecular & - & - & + & - & - & - & + & - & - & - \\
\hline 8 & primary & left forearm & intermediate & - & $+P$ & - & - & + & + & - & - & - & - \\
\hline 9 & $\begin{array}{l}\text { 9a LN met } \\
\text { 9b met }\end{array}$ & $\begin{array}{l}\text { 9a right axilla } \\
9 \mathrm{~b} \text { right thoracic wall }\end{array}$ & $\begin{array}{l}\text { small cell } \\
\text { small cell }\end{array}$ & $\begin{array}{l}- \\
-\end{array}$ & $\begin{array}{l}- \\
+L\end{array}$ & - & - & $\begin{array}{l}- \\
-\end{array}$ & $\begin{array}{l}- \\
-\end{array}$ & $\begin{array}{l}- \\
+\end{array}$ & - & $\begin{array}{l}- \\
-\end{array}$ & $\begin{array}{l}- \\
-\end{array}$ \\
\hline 10 & $\begin{array}{l}\text { 10a primary } \\
\text { 10b recurrence } \\
10 \mathrm{c} \text { met }\end{array}$ & $\begin{array}{l}\text { 10a left upper eyelid } \\
\text { 10b left upper eyelid } \\
\text { 10c parotid gland }\end{array}$ & $\begin{array}{c}\text { trabecular } \\
\text { intermediate } \\
\text { trabecular }\end{array}$ & $\begin{array}{l}- \\
- \\
-\end{array}$ & $\begin{array}{c}- \\
- \\
+L\end{array}$ & $\begin{array}{l}- \\
- \\
-\end{array}$ & $\begin{array}{l}- \\
- \\
-\end{array}$ & $\begin{array}{l}- \\
- \\
-\end{array}$ & $\begin{array}{l}- \\
- \\
-\end{array}$ & $\begin{array}{l}- \\
- \\
+\end{array}$ & $\begin{array}{l}- \\
- \\
-\end{array}$ & $\begin{array}{l}- \\
- \\
-\end{array}$ & $\begin{array}{l}+ \\
+ \\
+\end{array}$ \\
\hline 11 & $\begin{array}{l}\text { 11a primary } \\
\text { 11b recurrence } \\
\text { 11c LN met }\end{array}$ & $\begin{array}{l}\text { 11a left thoracic wall } \\
11 b \text { left thoracic wall } \\
11 \mathrm{c} \text { left axilla }\end{array}$ & $\begin{array}{l}\text { intermediate } \\
\text { trabecular } \\
\text { intermediate }\end{array}$ & $\begin{array}{l}- \\
- \\
-\end{array}$ & $\begin{array}{l}+L \\
+L \\
+L\end{array}$ & $\begin{array}{l}- \\
\text { n.d. } \\
-\end{array}$ & $\begin{array}{l}- \\
- \\
-\end{array}$ & $\begin{array}{l}- \\
- \\
-\end{array}$ & $\begin{array}{l}- \\
- \\
+\end{array}$ & $\begin{array}{l}+ \\
+ \\
+\end{array}$ & $\begin{array}{l}- \\
- \\
-\end{array}$ & $\begin{array}{l}+ \\
+ \\
-\end{array}$ & $\begin{array}{l}+ \\
+ \\
-\end{array}$ \\
\hline 12 & $\begin{array}{l}\text { 12a primary } \\
12 \mathrm{~b} \text { LN met }\end{array}$ & $\begin{array}{l}\text { 12a left lower leg } \\
12 b \text { left inguinal }\end{array}$ & $\begin{array}{l}\text { small cell } \\
\text { small cell }\end{array}$ & - & - & $\begin{array}{c}\text { n.d. } \\
-\end{array}$ & $\begin{array}{c}\text { n.d. } \\
-\end{array}$ & $\begin{array}{l}- \\
-\end{array}$ & $\begin{array}{c}- \\
\text { n.d. }\end{array}$ & $\begin{array}{l}- \\
+\end{array}$ & $\begin{array}{c}\text { n.d. } \\
-\end{array}$ & $\begin{array}{c}\text { n.d. } \\
-\end{array}$ & - \\
\hline 13 & primary & right eye brow & small cell & - & - & - & - & - & - & + & - & - & + \\
\hline 14 & $\begin{array}{l}\text { 14a primary } \\
14 \mathrm{~b} L N \text { met }\end{array}$ & $\begin{array}{l}\text { 14a right gluteal } \\
14 \mathrm{~b} \text { right inguinal }\end{array}$ & $\begin{array}{l}\text { small cell } \\
\text { small cell }\end{array}$ & - & $\begin{array}{l}+\mathrm{L} \\
+\mathrm{P}\end{array}$ & - & - & - & $\begin{array}{l}- \\
+\end{array}$ & $\begin{array}{l}+ \\
+\end{array}$ & - & $\begin{array}{c}\text { n.d. } \\
+\end{array}$ & $\begin{array}{l}+ \\
+\end{array}$ \\
\hline 15 & $\begin{array}{l}\text { 15a primary } \\
15 b \text { LN met }\end{array}$ & $\begin{array}{l}\text { 15a left gluteal } \\
15 \mathrm{~b} \text { left gluteal }\end{array}$ & $\begin{array}{l}\text { intermediate } \\
\text { intermediate }\end{array}$ & $\begin{array}{l}- \\
-\end{array}$ & $\begin{array}{l}- \\
-\end{array}$ & $\begin{array}{c}- \\
\text { n.d. }\end{array}$ & n.d. & $\begin{array}{l}\text { n.d. } \\
\text { n.d. }\end{array}$ & $\begin{array}{c}- \\
\text { n.d. }\end{array}$ & $\begin{array}{c}+ \\
\text { n.d. }\end{array}$ & $\begin{array}{l}- \\
+\end{array}$ & $\begin{array}{c}- \\
\text { n.d. }\end{array}$ & $\begin{array}{l}+ \\
-\end{array}$ \\
\hline
\end{tabular}




\begin{tabular}{|c|c|c|c|c|c|c|c|c|c|c|c|c|c|}
\hline 16 & primary & right forearm & trabecular & - & $+L$ & - & - & - & - & + & - & + & + \\
\hline 17 & LN met & right inguinal & intermediate & - & $+\mathrm{P}$ & - & - & - & + & + & + & - & + \\
\hline 18 & $\begin{array}{l}\text { 18a primary } \\
\text { 18b recurrence } \\
18 \mathrm{c} \text { LN met }\end{array}$ & $\begin{array}{l}18 \mathrm{a} \text { right thigh } \\
18 \mathrm{~b} \text { right thigh } \\
18 \mathrm{c} \text { right inguinal }\end{array}$ & $\begin{array}{l}\text { small cell } \\
\text { small cell } \\
\text { small cell }\end{array}$ & $\begin{array}{l}- \\
- \\
-\end{array}$ & - & - & $\begin{array}{l}- \\
-\end{array}$ & - & - & $\begin{array}{l}- \\
- \\
+\end{array}$ & $\begin{array}{l}+ \\
- \\
-\end{array}$ & $\begin{array}{l}- \\
+ \\
+\end{array}$ & $\begin{array}{c}\text { n.d. } \\
- \\
-\end{array}$ \\
\hline 19 & primary & n.d. & intermediate & - & $+L$ & - & + & - & - & + & + & + & + \\
\hline 20 & $\begin{array}{l}20 \text { a primary } \\
20 \mathrm{~b} \text { recurrence } \\
20 \mathrm{c} \text { recurrence } \\
20 \mathrm{~d} \text { LN met }\end{array}$ & $\begin{array}{l}\text { 20a right thigh } \\
20 \mathrm{~b} \text { right thigh } \\
20 \mathrm{c} \text { right thigh } \\
20 \mathrm{~d} \text { right inguinal }\end{array}$ & $\begin{array}{l}\text { small cell } \\
\text { small cell } \\
\text { small cell } \\
\text { small cell }\end{array}$ & $\begin{array}{l}- \\
- \\
-\end{array}$ & $\begin{array}{l}- \\
- \\
- \\
+P\end{array}$ & $\begin{array}{l}- \\
- \\
-\end{array}$ & $\begin{array}{l}- \\
- \\
-\end{array}$ & $\begin{array}{c}- \\
- \\
\text { n.d. } \\
-\end{array}$ & $\begin{array}{l}- \\
- \\
- \\
+\end{array}$ & $\begin{array}{l}+ \\
- \\
-\end{array}$ & $\begin{array}{l}- \\
- \\
+ \\
-\end{array}$ & $\begin{array}{l}+ \\
+ \\
- \\
-\end{array}$ & $\begin{array}{l}- \\
- \\
+ \\
+\end{array}$ \\
\hline 21 & $\begin{array}{l}\text { 21a recurrence } \\
21 b \text { LN met }\end{array}$ & $\begin{array}{l}\text { 21a left cheek } \\
\text { 21b left cervix }\end{array}$ & $\begin{array}{c}\text { intermediate } \\
\text { trabecular }\end{array}$ & - & $\begin{array}{l}+P \\
+P\end{array}$ & - & - & - & $\begin{array}{l}+ \\
+\end{array}$ & $\begin{array}{l}+ \\
+\end{array}$ & $\begin{array}{l}+ \\
-\end{array}$ & - & $\begin{array}{l}+ \\
+\end{array}$ \\
\hline 22 & primary & right elbow & trabecular & - & $+\mathrm{P}$ & - & - & - & - & + & + & + & + \\
\hline 23 & primary & left gluteal & small cell & - & $+P$ & n.d. & - & - & - & - & - & n.d. & + \\
\hline 24 & primary & left thigh & small cell & - & $+\mathrm{P}$ & - & - & - & - & - & + & - & + \\
\hline 25 & primary & right forearm & intermediate & - & $+L$ & - & - & - & - & + & + & + & - \\
\hline 26 & primary & right upper eyelid & intermediate & - & $+P$ & - & - & - & - & - & + & + & n.d. \\
\hline 27 & recurrence & left lower eyelid & trabecular & - & $+\mathrm{P}$ & - & - & - & + & - & + & - & - \\
\hline 28 & $\begin{array}{l}\text { 28a primary } \\
\text { 28b LN met }\end{array}$ & $\begin{array}{l}28 a \text { right cheek } \\
28 b \text { right cervix }\end{array}$ & $\begin{array}{l}\text { intermediate } \\
\text { intermediate }\end{array}$ & - & $\begin{array}{l}+P \\
+P \\
\end{array}$ & - & - & - & $\begin{array}{l}+ \\
+ \\
+\end{array}$ & - & $\begin{array}{l}+ \\
+ \\
\end{array}$ & - & $\begin{array}{l}+ \\
- \\
\end{array}$ \\
\hline 29 & primary & right temporal & intermediate & - & $+\mathrm{P}$ & n.d. & n.d. & - & n.d. & + & n.d. & n.d. & n.d. \\
\hline 30 & $\begin{array}{l}\text { 30a recurrence } \\
\text { 30b LN met }\end{array}$ & $\begin{array}{l}\text { 30a right lower leg } \\
30 \mathrm{~b} \text { right inguinal }\end{array}$ & $\begin{array}{l}\text { intermediate } \\
\text { intermediate }\end{array}$ & - & $\begin{array}{l}+P \\
+P \\
\end{array}$ & - & - & - & $\begin{array}{l}+ \\
+ \\
\end{array}$ & $\begin{array}{l}+ \\
+ \\
\end{array}$ & + & + & $\begin{array}{l}+ \\
+ \\
\end{array}$ \\
\hline 31 & primary & occiput & trabecular & - & - & - & - & - & + & - & + & - & - \\
\hline 32 & primary & right lower eyelid & small cell & - & - & - & - & - & - & + & - & - & - \\
\hline
\end{tabular}

$\mathrm{P}$ - punctuate pattern typical of desmosomes, $\mathrm{L}$ - linear immunofluorescence. 
Supplementary Table S3. Immunoreactions observed with antibodies to TJ proteins.

\begin{tabular}{|c|c|c|c|c|c|c|c|c|c|c|c|c|}
\hline $\begin{array}{l}\text { Pat } \\
\text { no. }\end{array}$ & Tumour & Localization & $\begin{array}{l}\text { Histological } \\
\text { subtype }\end{array}$ & $\begin{array}{l}\text { Clau- } \\
\text { din } 1\end{array}$ & $\begin{array}{l}\text { Clau- } \\
\text { din } 2\end{array}$ & $\begin{array}{l}\text { Clau- } \\
\text { din } 3\end{array}$ & $\begin{array}{l}\text { Clau- } \\
\text { din } 4\end{array}$ & $\begin{array}{l}\text { Clau- } \\
\text { din } 5\end{array}$ & $\begin{array}{l}\text { Occlu } \\
\text {-din }\end{array}$ & $\begin{array}{c}\text { JAM- } \\
\text { A }\end{array}$ & ZO-1 & ZO-2 \\
\hline 1 & $\begin{array}{l}\text { 1a primary } \\
\text { 1b LN met }\end{array}$ & $\begin{array}{l}\text { 1a right knee } \\
\text { 1b right inguinal }\end{array}$ & $\begin{array}{l}\text { trabecular } \\
\text { trabecular }\end{array}$ & $\begin{array}{l}- \\
-\end{array}$ & $\begin{array}{l}- \\
-\end{array}$ & $\begin{array}{l}- \\
-\end{array}$ & $\begin{array}{l}- \\
-\end{array}$ & $\begin{array}{l}+ \\
+\end{array}$ & $\begin{array}{l}+ \\
-\end{array}$ & $\begin{array}{l}- \\
-\end{array}$ & $\begin{array}{l}- \\
-\end{array}$ & $\begin{array}{l}+ \\
+\end{array}$ \\
\hline 2 & $\begin{array}{l}\text { 2a primary } \\
\text { 2b LN met } \\
\text { 2c LN met }\end{array}$ & $\begin{array}{l}\text { 2a left ear } \\
2 b \text { left cervix } \\
2 c \text { left cervix }\end{array}$ & $\begin{array}{l}\text { intermediate } \\
\text { intermediate } \\
\text { intermediate }\end{array}$ & $\begin{array}{c}+ \\
\text { n.d. } \\
-\end{array}$ & $\begin{array}{l}- \\
- \\
-\end{array}$ & $\begin{array}{l}+ \\
+ \\
+\end{array}$ & $\begin{array}{l}+ \\
+ \\
-\end{array}$ & $\begin{array}{l}+ \\
+ \\
+\end{array}$ & $\begin{array}{l}+ \\
+ \\
+\end{array}$ & $\begin{array}{l}+ \\
+ \\
-\end{array}$ & $\begin{array}{l}+ \\
- \\
-\end{array}$ & $\begin{array}{l}+ \\
+ \\
-\end{array}$ \\
\hline 3 & recurrence & gluteal & small cell & - & - & - & - & - & - & + & - & n.d. \\
\hline 4 & primary & left ala of the nose & intermediate & - & - & - & - & + & + & - & - & + \\
\hline 5 & $\begin{array}{l}\text { 5a primary } \\
\text { 5b LN met }\end{array}$ & $\begin{array}{l}5 a \text { left lower leg } \\
5 b \text { left inguinal }\end{array}$ & $\begin{array}{c}\text { trabecular } \\
\text { intermediate }\end{array}$ & - & n.d. & $\begin{array}{c}+ \\
\text { n.d. }\end{array}$ & - & + & + & $\begin{array}{l}+ \\
+ \\
\end{array}$ & $\begin{array}{l}+ \\
+ \\
\end{array}$ & - \\
\hline 6 & primary & right elbow & small cell & + & - & + & + & + & + & + & + & + \\
\hline 7 & primary & left elbow & trabecular & - & - & + & - & + & + & - & - & + \\
\hline 8 & primary & left forearm & intermediate & + & - & - & - & - & - & + & + & - \\
\hline 9 & $\begin{array}{l}\text { 9a LN met } \\
\text { 9b met }\end{array}$ & $\begin{array}{l}\text { 9a right axilla } \\
\text { 9b right thoracic wall }\end{array}$ & $\begin{array}{l}\text { small cell } \\
\text { small cell }\end{array}$ & - & - & $\begin{array}{l}+ \\
+\end{array}$ & - & $\begin{array}{l}- \\
+\end{array}$ & $\begin{array}{l}- \\
+\end{array}$ & $\begin{array}{l}- \\
+\end{array}$ & $\begin{array}{l}- \\
+\end{array}$ & - \\
\hline 10 & $\begin{array}{l}\text { 10a primary } \\
\text { 10b recurrence } \\
\text { 10c met }\end{array}$ & $\begin{array}{l}\text { 10a left upper eyelid } \\
\text { 10b left upper eyelid } \\
\text { 10c parotid gland }\end{array}$ & $\begin{array}{l}\text { trabecular } \\
\text { intermediate } \\
\text { trabecular }\end{array}$ & $\begin{array}{l}+ \\
+ \\
-\end{array}$ & $\begin{array}{l}- \\
- \\
-\end{array}$ & $\begin{array}{l}- \\
- \\
+\end{array}$ & $\begin{array}{l}- \\
- \\
-\end{array}$ & $\begin{array}{l}+ \\
+ \\
+\end{array}$ & $\begin{array}{l}+ \\
+ \\
-\end{array}$ & $\begin{array}{l}- \\
+ \\
+\end{array}$ & $\begin{array}{l}+ \\
+ \\
+\end{array}$ & $\begin{array}{l}+ \\
- \\
+\end{array}$ \\
\hline 11 & $\begin{array}{l}\text { 11a primary } \\
\text { 11b recurrence } \\
\text { 11c LN met }\end{array}$ & $\begin{array}{l}\text { 11a left thoracic wall } \\
11 \mathrm{~b} \text { left thoracic wall } \\
\text { 11c left axilla }\end{array}$ & $\begin{array}{l}\text { intermediate } \\
\text { trabecular } \\
\text { intermediate }\end{array}$ & $\begin{array}{l}- \\
- \\
+\end{array}$ & $\begin{array}{l}- \\
- \\
-\end{array}$ & $\begin{array}{l}+ \\
+ \\
+\end{array}$ & $\begin{array}{l}- \\
- \\
-\end{array}$ & $\begin{array}{l}+ \\
+ \\
+\end{array}$ & $\begin{array}{l}+ \\
+ \\
+\end{array}$ & $\begin{array}{l}+ \\
+ \\
+\end{array}$ & $\begin{array}{l}+ \\
- \\
+\end{array}$ & $\begin{array}{l}+ \\
- \\
+\end{array}$ \\
\hline 12 & $\begin{array}{l}\text { 12a primary } \\
12 b \text { LN met }\end{array}$ & $\begin{array}{l}12 a \text { left lower leg } \\
12 b \text { left inguinal }\end{array}$ & $\begin{array}{l}\text { small cell } \\
\text { small cell }\end{array}$ & $\begin{array}{c}\text { n.d. } \\
-\end{array}$ & $\begin{array}{c}\text { n.d. } \\
-\end{array}$ & $\begin{array}{l}- \\
-\end{array}$ & $\begin{array}{c}\text { n.d. } \\
-\end{array}$ & $\begin{array}{l}+ \\
-\end{array}$ & - & $\begin{array}{c}\text { n.d. } \\
-\end{array}$ & $\begin{array}{l}- \\
+\end{array}$ & $\begin{array}{l}- \\
-\end{array}$ \\
\hline 13 & primary & right eye brow & small cell & + & - & + & - & + & - & - & - & + \\
\hline 14 & $\begin{array}{l}\text { 14a primary } \\
14 \mathrm{~b} \text { LN met }\end{array}$ & $\begin{array}{l}14 \mathrm{a} \text { right gluteal } \\
14 \mathrm{~b} \text { right inguinal }\end{array}$ & $\begin{array}{l}\text { small cell } \\
\text { small cell }\end{array}$ & - & - & $\begin{array}{l}+ \\
+\end{array}$ & - & $\begin{array}{l}+ \\
+\end{array}$ & $\begin{array}{l}+ \\
+\end{array}$ & $\begin{array}{l}+ \\
+\end{array}$ & $\begin{array}{l}+ \\
+\end{array}$ & $\begin{array}{l}+ \\
+\end{array}$ \\
\hline 15 & $\begin{array}{l}\text { 15a primary } \\
15 b \text { LN met }\end{array}$ & $\begin{array}{l}\text { 15a left gluteal } \\
15 b \text { left gluteal }\end{array}$ & $\begin{array}{l}\text { intermediate } \\
\text { intermediate }\end{array}$ & - & $\begin{array}{c}\text { n.d. } \\
-\end{array}$ & $\begin{array}{c}+ \\
\text { n.d. }\end{array}$ & n.d. & $\begin{array}{l}+ \\
+\end{array}$ & $\begin{array}{l}- \\
+\end{array}$ & $\begin{array}{c}+ \\
\text { n.d. }\end{array}$ & n.d. & $\begin{array}{l}- \\
+\end{array}$ \\
\hline
\end{tabular}




\begin{tabular}{|c|c|c|c|c|c|c|c|c|c|c|c|c|}
\hline 16 & primary & right forearm & trabecular & - & - & + & - & + & + & - & + & + \\
\hline 17 & LN met & right inguinal & intermediate & - & - & + & + & + & + & - & + & + \\
\hline 18 & $\begin{array}{l}\text { 18a primary } \\
\text { 18b recurrence } \\
\text { 18c LN met }\end{array}$ & $\begin{array}{l}18 \mathrm{a} \text { right thigh } \\
18 \mathrm{~b} \text { right thigh } \\
18 \mathrm{c} \text { right inguinal }\end{array}$ & $\begin{array}{l}\text { small cell } \\
\text { small cell } \\
\text { small cell }\end{array}$ & $\begin{array}{l}- \\
- \\
-\end{array}$ & $\begin{array}{l}- \\
- \\
-\end{array}$ & $\begin{array}{l}- \\
- \\
-\end{array}$ & $\begin{array}{l}- \\
-\end{array}$ & $\begin{array}{l}+ \\
- \\
+\end{array}$ & $\begin{array}{l}- \\
- \\
+\end{array}$ & $\begin{array}{l}- \\
- \\
-\end{array}$ & $\begin{array}{l}- \\
- \\
-\end{array}$ & $\begin{array}{l}- \\
- \\
-\end{array}$ \\
\hline 19 & primary & n.d. & intermediate & + & - & + & - & + & + & + & - & + \\
\hline 20 & $\begin{array}{l}\text { 20a primary } \\
20 b \text { recurrence } \\
20 c \text { recurrence } \\
20 d \text { LN met }\end{array}$ & $\begin{array}{l}20 \mathrm{a} \text { right thigh } \\
20 \mathrm{~b} \text { right thigh } \\
20 \mathrm{c} \text { right thigh } \\
20 \mathrm{~d} \text { right inguinal }\end{array}$ & $\begin{array}{l}\text { small cell } \\
\text { small cell } \\
\text { small cell } \\
\text { small cell }\end{array}$ & $\begin{array}{l}- \\
- \\
- \\
+\end{array}$ & $\begin{array}{l}- \\
- \\
- \\
-\end{array}$ & $\begin{array}{l}+ \\
- \\
- \\
+\end{array}$ & $\begin{array}{l}- \\
- \\
- \\
-\end{array}$ & $\begin{array}{l}+ \\
- \\
+ \\
+\end{array}$ & $\begin{array}{l}- \\
- \\
+ \\
+\end{array}$ & $\begin{array}{l}- \\
+ \\
- \\
+\end{array}$ & $\begin{array}{l}+ \\
+ \\
+ \\
+\end{array}$ & $\begin{array}{l}+ \\
- \\
- \\
+\end{array}$ \\
\hline 21 & $\begin{array}{l}\text { 21a recurrence } \\
21 b \text { LN met }\end{array}$ & $\begin{array}{l}21 \mathrm{a} \text { left cheek } \\
21 \mathrm{~b} \text { left cervix }\end{array}$ & $\begin{array}{c}\text { intermediate } \\
\text { trabecular }\end{array}$ & - & - & $\begin{array}{l}+ \\
+ \\
\end{array}$ & - & $\begin{array}{l}+ \\
+ \\
\end{array}$ & $\begin{array}{l}+ \\
+ \\
\end{array}$ & $\begin{array}{l}+ \\
+ \\
\end{array}$ & $\begin{array}{l}+ \\
+ \\
\end{array}$ & $\begin{array}{l}+ \\
- \\
\end{array}$ \\
\hline 22 & primary & right elbow & trabecular & - & - & + & - & + & + & + & + & + \\
\hline 23 & primary & left gluteal & small cell & - & - & - & - & + & - & n.d. & + & + \\
\hline 24 & primary & left thigh & small cell & - & - & - & - & + & - & - & - & - \\
\hline 25 & primary & right forearm & intermediate & - & - & + & + & + & - & + & + & + \\
\hline 26 & primary & right upper eyelid & intermediate & - & - & + & - & + & - & - & - & + \\
\hline 27 & recurrence & left lower eyelid & trabecular & - & - & - & - & + & - & + & + & + \\
\hline 28 & $\begin{array}{l}\text { 28a primary } \\
28 b \text { LN met }\end{array}$ & $\begin{array}{l}28 a \text { right cheek } \\
28 b \text { right cervix }\end{array}$ & $\begin{array}{l}\text { intermediate } \\
\text { intermediate }\end{array}$ & - & - & $\begin{array}{l}+ \\
+\end{array}$ & $\begin{array}{l}- \\
+\end{array}$ & $\begin{array}{c}+ \\
\text { n.d. }\end{array}$ & $\begin{array}{l}+ \\
+\end{array}$ & $\begin{array}{l}+ \\
+\end{array}$ & $\begin{array}{l}+ \\
+\end{array}$ & $\begin{array}{l}+ \\
+\end{array}$ \\
\hline 29 & primary & right temporal & intermediate & n.d. & n.d. & n.d. & n.d. & n.d. & n.d. & n.d. & n.d. & n.d. \\
\hline 30 & $\begin{array}{l}\text { 30a recurrence } \\
\text { 30b LN met }\end{array}$ & $\begin{array}{l}\text { 30a right lower leg } \\
\text { 30b right inguinal }\end{array}$ & $\begin{array}{l}\text { intermediate } \\
\text { intermediate }\end{array}$ & $\begin{array}{l}- \\
+\end{array}$ & - & $\begin{array}{l}+ \\
+\end{array}$ & - & $\begin{array}{l}+ \\
+\end{array}$ & $\begin{array}{l}+ \\
-\end{array}$ & $\begin{array}{l}+ \\
+\end{array}$ & - & $\begin{array}{l}+ \\
+\end{array}$ \\
\hline 31 & primary & occiput & trabecular & - & - & + & - & + & + & + & - & + \\
\hline 32 & primary & right lower eyelid & small cell & - & - & - & - & + & - & - & + & + \\
\hline
\end{tabular}

